\title{
A Critical Discourse Analysis of Internal Intertextuality in American and Egyptian News Reporting on Egypt's January 25 and June 30 Protests
}

By Hebatollah M. M. Hegazy

\author{
Assistant Lecturer \\ English Department \\ Faculty of Education \\ Alexandria University
}




\section{Abstract}

This study aims at investigating the similarities and/or differences in the representation of both Egyptian January the 25th and June the 30thprotests and their key social actors (Mubarak's and Morsi's regimes and the anti- and pro-regimes protesters) in the discourse of the mainstream American newspaper, The New York Times, and the mainstream Egyptian newspaper, Al-Masry Al-Youm. The study explores the international and national press ideological perspectives on both protests and examines the extent to which such differential perspectives by the two news outlets have been consistently reflective of the official mainstream ideological views, and hence contributing to the notion of media as an ideological state apparatus (ISA). The study has adopted Fairclough's (1995a) three-layer model of critical discourse analysis (CDA) and complemented it with van Dijk's (2000) ideological square in order to investigate internal intertextuality considered by Richardson (2007) as one of the essential discursive practices of journalism. The analysis of internal intertextuality in the present study encompasses Fairclough's (2003) framing of voices, Chen's $(2005,2007)$ analytic tool of communicative verbal processes, and Richardson's (2007) four types of quotation that he believed are most relevant to news reporting discourse.The study analyzes 32 news reports covering both Egyptian protests from the eruption of each to the downfall of both regimes (more specifically, from Jan. 25 to Feb. 11, 2011; and from Nov. 22, 2012 to July 3, 2013), focusing on five key events during each protest. The results have revealed that each newspaper's stance towards both protests has been ideologically-slanted and tremendously fed by its political affiliation, hence giving support to the notion of the media as an ISA.

Key words: Critical Discourse Analysis; Ideological Square; Ideological State Apparatus; Internal Intertexuality 


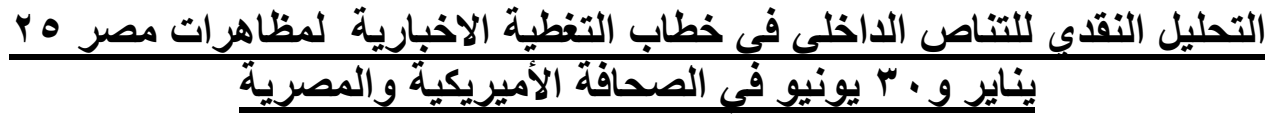
الملخص العربي

تهدف هذه الدراسة لفحص أوجه التشابه والاختلاف بين الصحيفتين السائدتيننيويورك نايمز

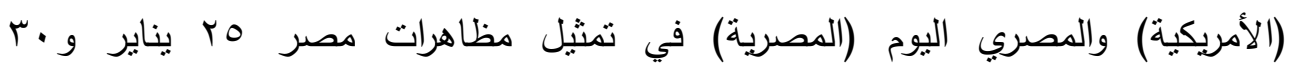
يونيووأطرافها الأساسية (نظامي مبارك و ومرسي والمتظاهرين المؤيدين والمعارضين لأنظمتهما)في خطابهما الأخباري. فهذه الدراسة تستكثف المناظير الأيديولوجية الصحفية العالمية والقومية للثورتين و تقحص المدى الذي به قد عكست هذه المناظير الإيديولوجية

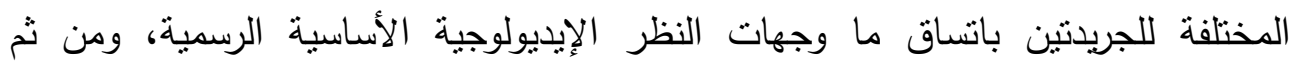
المساهمة في مفهوم الإعلام كجهاز دولة أيديولوجي. وقد اتبعت الدراسة في إطارها التحليلي نموذج فيركلوف (990) ثلاثي المراحل الخاص بالتحليل النقدي للخطاب بالاضافة الى لى لئي

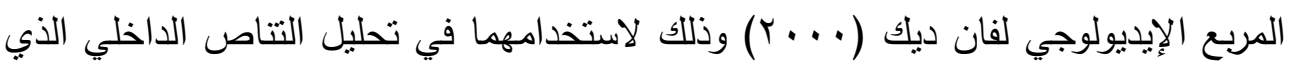

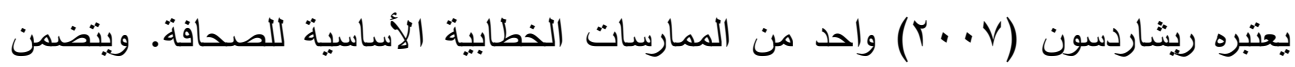

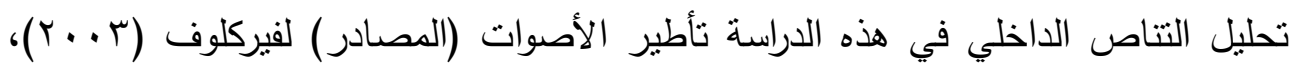

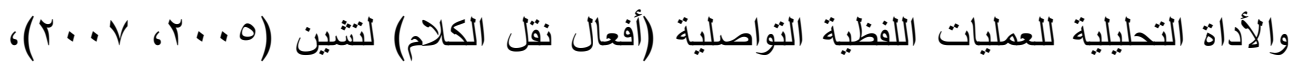



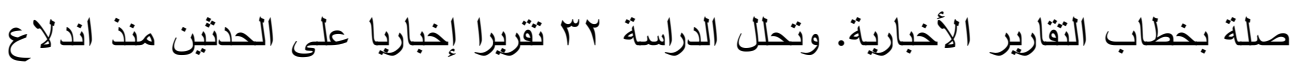

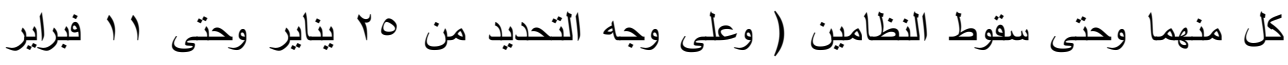

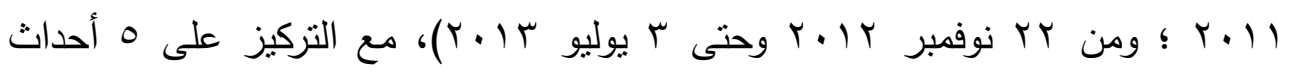

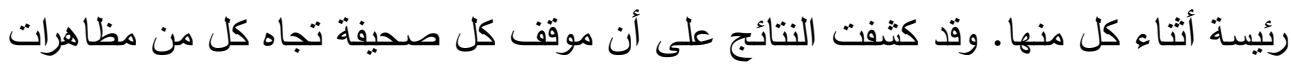

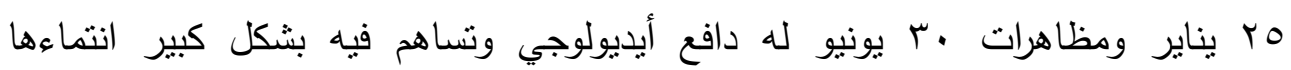

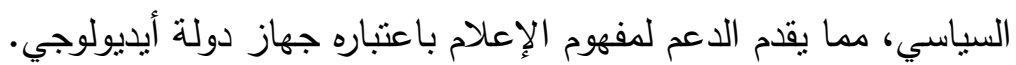

الكلمات المفتاحية: التحليل النقدي للخطاب، المربع الإيديولوجي، جهاز دولة أيديولوجي، التناص الداخلي 


\section{Introduction}

The present study investigates the representation of the Egyptian January 25 and June 30 protests in the online versions of two mainstream newspapers; namely, TheNew York Times (American) and Al-Masry Al-Youm (Egyptian). The first newspaper reflects the international perspective on both Egyptian protests, particularly the US', whereas the second newspaper represents the national perspective on both protests. The current study examines the news reports covering the extended protest periods from the eruption of each to the ouster of the ruling president. The study uses the critical discourse analytical approach (CDA), particularly Fairclough's (1995a) three-layer model of CDA and van Dijk's (2000) ideological square to qualitatively analyze the news stories so as to uncover the above newspapers' ideological perspectives on the two protests, expose the frequently hidden power relationships, and highlight the influence of powerful groups and institutions in society on mainstream media, as held by a number of scholars (Althusser, 1971; Fairclough, 1994, 2003, 2006; Herman \& Chomsky, 2002; Richardson, 2007; van Dijk, 1991, 1993a, 1996, 1998, 2000).

Ashley and Olson (1998) as well as McQuail (1993) argued that media are given some responsibility whenever the stability of a society is at stake by war, crime, economic disaster, social protests, etc. Consequently, the media are more likely to support the legitimacy of the state and delegitimize the challenges of social orders. In correspondence to the assumptions of the aforementioned scholars, I argue that the two examined newspapers' representation of the anti-Mubarak and anti-Morsi protests could be influenced by the official mainstream perspectives on both protests. However, the extent of such influence may vary based on the political affiliation of each newspaper. In fact, news reporting discourse, in particular, is chosen for analysis as it includes ideas and attitudes, not merely 
facts, as held by van Dijk (1991), despite being widely known as the most informative press discourse and hence supposedly impartial. Accordingly, the present study is expected to enhance the reader's knowledge and awareness of the manipulative nature of the news reporting discourse, thus promoting their critical abilities in reading newspapers. The present study aims to unveil the ideologies of both newspapers towards both protests and their key social actors (i.e. both presidents, their governments, their pro- and anti-regime protesters, and the army)through examining their use of internal intertexuality (quotation and reported speech), being one of the most commondiscursive practices of Press discourse (Richardson, 2007). It also investigates the extent to which such newspapers' ideologies have been steadily indicative of the official mainstream ideological perspectives and fed by their political affiliations, and hence giving support to the notion of media as an ideological state apparatus (ISA) in the sense of Althusser (1971).

To my best knowledge, comparing and contrasting the representation of the January 25 and June 30 protests in the Americanand Egyptian press received little attention. I have found only one study (El-Nashar, 2014) handling such a topic in one American newspaper, using a CDA framework and a quantitative approach.El-Nashar examined only the army's role in both protests, which is not the focus of the present study. Hence, the current study extends the scope of research by attempting to reveal how similar and/or different the ideologies of the Western and Egyptian mainstream newspapers at issue are towards both protests and the main social actors involved, apart from the military institute. Such institute cannot be considered as belonging to the regime or its opponents during both protests since it had its own decisive role during both protests.Moreover, the current study also adds to the body of qualitative research on the Arab Middle East, particularly the issue of the Arab Spring, 
which contributes to bridging the gap between the linguistic, on the one hand, and the media, social, and political, on the other hand. Finally, the fact that both protests are recent historic events in Egypt lends an important element of timeliness and per se significance to the present study.

\section{Research Objectives}

The current study has the following objectives:

1. Revealing the similarities and/or differences in the representation of both Egyptian protests in the discourse of the mainstream American The New York Times (i.e. the international press perspective) and the mainstream Egyptian Al-MasryAl-Youm (i.e. the national press perspective).

2. Unveiling the extent to which both newspapers' differential perspectives on both protests have been consistently reflective of the official mainstream ideological views, thus contributing to the notion of media as an ISA.

The study purports to answer the following questions:

1. How far does The New York Times'and Al-Masry Al-Youm's use of internal intertextualityreflect similarities and/or differences in theirrepresentation of the Egyptian January 25 and June 30 protestswith regard to the key social actors, namely, Mubarak's and Morsi's regimes and the anti- and proregimes protesters as well as five key events during each?

2. To what extent have both mainstream newspapers' international and national ideological perspectives on both protestsbeen constantly indicative of the official ideological views, and hence endorsing the notion of media as an ISA in the sense of Althusser (1971)? 


\section{Review of Literature}

In the words of van Dijk (2001), CDA "studies the way social power abuse, dominance, and inequality are enacted, reproduced, and resisted by text and talk in the social and political context" (p. 353). CDA is concerned with highlighting the interrelationships between language, power, and ideology which may be hidden from people, as explained in the works of Fairclough (1989, 1992, 1995a), Fairclough and Wodak (1997), Hodge and Kress (1993), van Dijk (1980, 1983, 1991, 1995a, 1995b, 1996, 1997, 2001), and Wodak (1996). According to them, CDA aims at the following:

- Addressing social and political issues.

- Highlighting how power and dominance relations operate through language.

- Establishing the relationship between society and text which is mediated by order of discourse, i.e. structured sets of discursive practices associated with particular social domains.

- Revealing the ideologies underlying discursive and social structures.

In so doing, CDA explores which ideologies the controlling groups use to dominate the controlled groups through language within a society and this is in particular what makes CDA a critical approach to discourse analysis (Rogers, 2004).

Ideology, as explained by van Dijk (1996), is "basic systems of shared social representations that may control more specific group beliefs (knowledge, attitudes), and influence models via the instantiation of such beliefs in concrete models of situations and experiences" (p. 7). Ideology, as regarded by Fairclough (2003), is a modality of power more than just being a coherent set of beliefs or values; it produces, reproduces, and challenges social relations of power, and hence representing the world. One 
important aspect of ideologies, according to van Dijk (2000), is manifested in the role they play in maintaining social group relations such as justifying and legitimizing domination, power abuse, and social inequality, on the one hand, and organizing opposition, resistance, and change, on the other. In this regard, ideologies, as van Dijk argued, represent social struggles; this necessitates representing the groups involved in such struggles in terms of group polarization, i.e. a representation of "Us", how we see ourselves, versus "Them", how we see others. In this concern, we represent ourselves positively as superior and represent others negatively as inferior. In other words, van Dijk's ideological square can help show how each examined newspaper identified the ingroup and the outgroup in the struggle between the regime and its opponents during both Egyptian protests through deemphasizing the negative actions of the ingroup and positive actions of the outgroup, on the one hand, while emphasizing the positive actions of the ingroup and negative actions of the outgroup, on the other.

It is important, accordingly, to shed light on Althusser's (1971) notion of the ISA in association with media discourse, particularly news reporting discourse due to its vital role in investigating such discourse as a form of social practice that may construct, foster, or challenge particular ideologies and power relations fed by the society's powerful elite people and institutions. One of the first to affirm that the media are not the voice of the average of normal person but rather are the voice of the powerful is Althusser in his Marxist account of ideology. He indicated that in order to produce and sustain dominance over society, a state must reproduce the conditions of production; otherwise, the state would lose dominance because state power is the exercise that guarantees the reproduction of relations of power within society. Althusser further emphasized that there are two types of apparatus that aim at reproducing the relations of 
power, namely, Repressive State Apparatus (RSA) and Ideological State Apparatus (ISA). He explained that the RSA is concerned with coercive power, i.e. hard power and includes the government, army, police, prisons, etc. The ISA, in which Althusser was particularly interested, is concerned with persuasive power, i.e. soft power and includes institutions that fall partly outside of state control but still serve to transmit the values of the state, such as the school, the Church, the legal system, the family, and the media. That is, as Althusser put it, the ISA aims at persuading the dominated groups to take the unequal power relations for granted and to regard them as being commonsensical and natural.

Mass media are a tool for representing ideological tendencies; they give access to hidden power relations (van Dijk, 1996). In the same vein, Herman and Chomsky (2002) underpinned that the mass media have a significant role as system-supportive propaganda. They argued that commercial media institutions form and define people's norms and beliefs according to the social, political, and economic interests dominating the state. In this sense, the media mobilize the public to support the social interests of the elite, and the dominant ideology of a society serves as its criterion for common sense and rational understanding (Herman \& Chomsky, 2002).

News is a representation of construction; it is not a valuefree reflection of facts but rather reported from a particular perspective, being controlled by economic, political, and social institutions which express and implement their social meanings and values through language, as held by Fowler (1991). In line with Fowler, van Dijk (2000) elucidated that news discourse arises from the current social or political conflicts and struggles between individuals or social groups. Accordingly, each social group has its own version of social reality which is defended and expressed in such discourse, but the version that becomes 
dominant and naturalized is that of the powerful elites (van Dijk, 2000). In agreement with Fowler (1991) and van Dijk (2000), Richardson (2007) pointed out that newspaper discourse is a medium of power and acts in ideological ways. Journalists, in the discourse process suggested by CDA, act upon the world through maintaining or transforming social beliefs as well as producing and reproducing social realities (Richardson, 2007). Here emerges Richardson's description of news reports as being prejudiced, explicating that the media institutions policies direct them; otherwise, all the media outlets would relatively report all news in the same way. Therefore, it can be concluded that news reporting is not valueless, i.e. not neutral and, on occasion, is fundamentally biased owing to the fact that value judgments are integrated into the news making process at all stages, notably, newsgathering, news writing, story selection, editing, and presentation, as explained by Richardson.

Fairclough's (1995a) three-layer model of CDA is adopted, for it is one of the most comprehensive frameworks of CDA which was developed throughout his works (e.g. Chouliaraki \& Fairclough, 1999; Fairclough, 1989, 1992, 1993, 1995a, 1995b), and others. At the core of Fairclough's approach to CDA is a view of discourse at three levels, namely, textual analysis referred to as "a language text" ("description"), text production and consumption referred to as "discourse practice" ("interpretation"), and the wider social context around its production and consumption referred to as "sociocultural practice" ("explanation") (p. 97). Hence, as Fairclough maintained, his framework of CDA can be employed in investigating social issues like those tackled in press discourse, which is the focus of the present study.

As far as the description level of analysis is concerned, Fairclough (1995a) stated textual analysis involves the analysis of the way propositions are structured, combined and sequenced. 
He pointed out that language use is simultaneously constitutive of social identities, social relations, and systems of knowledge and beliefs. That is, the language used is selected and controlled to achieve specific social purposes, and the analyst may pay attention to any or all of the grammar, lexis, intonation, and cohesive devices used, as well as global meanings.

As for the interpretation level of analysis, it refers to the way that actual discourse is institutionally determined (Fairclough, 1995a). Indeed, text production and interpretation are embedded in institutional discourse practices and therefore mediate between the sociocultural practice (the area of context) and text. Fairclough argued that it is at the interpretation level that the implicit meanings underlying any given discourse are unveiled through revealing what people have in their mind such as their beliefs, ideologies, and knowledge of language.

In the explanation level of analysis, Fairclough (1995a) underscored that discourse as social practice means that language is a social process. He explained that the social context of our lives, which includes all the elements both linguistic and nonlinguistic, shapes the ways in which we use language; this provides the context for how we interpret and understand the world. In other words, discourse at the level of context involves the social conditions of the production and interpretation of meaning. Thus, the actual power of the text cannot be described unless reference is made to the wider social models of the world, as held by Fairclough. He highlighted that the analysis of such socio-cultural context of which a particular event is part may involve its immediate situational context, the wider context of institutional practices within which the event is embedded, or the yet wider frame of the society and culture.

In the present study, internal intertextualityis explored since news includes certain happenings, excludes others, and sets these 
events in a particular relation to each other, and part of making the story is the representation of voices and speech (Fairclough, 2003). According to Richardson (2007), internal intertextuality refers to quotations and reported speech; news reporting necessarily reproduces the actions and views of others. Investigating internal intertextuality is of great importance to the current study, for news reports weave a range of voices together in order to interpret events, and the voice of the social actors whether officials or men on the street and whether directly quoted or paraphrased reveals to what extent news reporting may be considered prejudicial (Iggers, 1999; Richardson, 2007). Consequently, this uncovers the ideologies and power relations underlying the examined newspapers' citing of voices. Since a news report may include a quote from a source either involved in the reported event or commenting on it, the journalist is in control of the process of selecting and framing the voices (Fairclough, 2003).In addition, news outlets, on the one hand, often legitimize the voices of the ingroup, while, on the other hand, represent the outgroup as unreliable sources, and thus they are not reported as frequently as the ingroup, as held by van Dijk (2000).

Richardson (2007) underscored four types of reported speech that he believed are most relevant to the analysis of news reporting discourse; these types are incorporated in the collected data and represent the following:

- Direct quotation: comprising the exact words of the speaker in quotation marks with a reporting clause.

- Strategic quotation or scare quotes: placing a particular word or phrase of the reported speech, writing, or thoughts of others in quotation marks in order to indicate contentious truth claims or that the truth claims are not the reporter's, i.e. reporting is not prejudicial.

- Indirect quotation: presenting a summary of the content of what was said or written with a reporting clause and with no quotation marks. 
- Transformed indirect quotation: dispensing with quotation marks and replacing reporting verbs like "said" with transitive actions like "discover" or mental state verbs like "believe" to fit with the newspaper's agenda.

(Summarized from Richardson, 2007, pp. 102-105)

As Teo (2000) put it, quotation patterns can act as a powerful ideological tool to manipulate readers' perception and interpretation of people and events in news reports. This is because citing in certain ways influences the factualness of the cited speech content (van Ginneken, 2002).To expound, strategic quotation reflects the journalist's disapproval of the quoted speech, or his doubt about its factualness (Bell, 1991; Juan, 2009; van Ginneken, 2002). In contrast, direct quotation indicates that the speech content is indisputable, which renders it persuasive and newsworthy and helps the reporter distance himself from the quoted speech (Bell, 1991; Cotter, 2010; Fairclough, 1994, 1995b, 2003; Richardson, 2007;Sornig, 1989; van Dijk, 1993a; van Ginneken, 2002). Indirect quotation, unlike both types above, distorts the original words said to the extent that they may change to be the reporter's; hence, it is difficult to distinguish the voice of the reported from that of the reporter, which gives power to the latter to transform the speech content in a way that makes it biased against or towards a specific party or group (de Graaf, 2008; Fairclough, 1994, 1995b, 2003; van Dijk, 1988). Both direct and indirect quotations are the most common in the data under analysis (see Tables 1-4, pp. 30-37).

Fairclough (2003) stated, "When the voice of another is incorporated into a text, there are always choices about how to frame it, how to contextualize it, in terms of other parts of the text - about relations between report and authorial account" (p. 53). Thus, intertextuality is a matter of recontextualization entailing certain transformations based upon how the represented discourse 
figures in the new context, i.e. the representing discourse, as held by Fairclough. Accordingly, the critical analysis of internal intertextualityin the present study is based on the following paraphrased criteria provided byFairclough in this respect:

- The voices included and the voices significantly excluded.

- Intertextuality specifically attributed to particular people or vaguely attributed (i.e. the anonymity of the voiced sources makes it hard to challenge what they said).

- The presence or absence of voices that criticize others and if present, the manner they are utilized and the significance of such criticism.

- The way the incorportated voices are textured in relation to the authorial voice and in relation to each other.

- The implemented voices in the wrap-up.

- The difference in the use of the various types of quotation like, e.g. the direct and the indirect quotations.

(Summarised from Fairclough, 2003, pp. 47-54)

What is also important to the analysis of quotes and reports are the reporting verbs employed by the authorial voice to cite voices. In fact, the analysis of such verbal processes in media texts can unveil much about both the journalist's attitude towards the quoted speaker and the way by which the journalist can lead the reader to adopt a certain view of that speaker (Bell, 1991; Chen, 2005, 2007; Eissa, 2015; Fairclough, 2003). Chen $(2005,2007)$ identified three sub-categories of verbal process: positive, negative, and neutral, which can indicate, respectively, the journalist's positive bias, negative bias, and impartiality towards the speaker.Chen defined each of the above categories and gave examples on each that, as she argued, are far from being comprehensive or ultimate. To illustrate, first, the neutral verbal processes reflect the writer's choice neither to endorse nor 
to disagree with what the quoted speaker is saying, such as "said", "agreed", "estimated", "asked", "told", "described", etc (Chen, 2005, pp. 48-51). Second, the negative verbal processes convey an element of doubt or skepticism as to the veracity of the reported speaker's words and demonstrate a certain negativity of feeling (bias) on the part of the writer towards the speaker, such as "insisted", "claimed", "admitted", "complained", "denied", "shouted", etc (Chen, 2005, pp. pp. 4146). Third, the positive verbal processes, as Chen (2007) explained, somehow promote in the reader a feeling that the cited voice is wise, decisive, strong, authoritative, confident, or in some other sense positive. Chen divided such positive reporting verbs into six sub-categories according to the role they assign to the quoted speaker and to the relationship of this speaker with other participants featuring in the news reports alongside him/her. These categories comprise declarative verbs (e.g. declared), authoritative (e.g. ordered), exhortative (e.g. urged), accusative (e.g. accused), informative (e.g. reported), and predicative (e.g. will demand) (Chen, 2007, pp 37-51).

A number of studies investigating the representation of Egyptian January 25 protests in the press discourse using CDA tenets and tools were carried out. However, to the researcher's knowledge, no study used CDA to investigate the quoted sources whether in the international and/or national independent press except Youssef's (2012) study. Furthermore, all the studies on the representation of Morsi's presidential era in the press discourse using CDA tackled only the portrayal of either Morsi, the Muslim Brotherhood (MB), and/or the political forces whether liberals, seculars, and Islamists during his rule up to but not including the June 30 anti-regime protests and Morsi's downfall. Only one of these studies, namely, Eissa (2015) is selected to be reviewed due to its investigation of the quoted voices on the part of the main social actors involved in the anti-Morsi protests 
during two key events discussed in the present study, namely, Morsi's constitutional declaration and the approval of the draft constitution as well as their repercussions.Comparing and contrasting the portrayal of both anti-regime protests in the national and international press discourse have not been examined.Even El-Nashar's (2014) study on the representation of the army's role in both protests in the American pressdid not investigate internal intertextuality. Thus, the present study attempts to fill in these gaps.

Youssef's (2012) study used Fairclough's CDA model and van Dijk's ideological square in its investigation of the ideological differences of Egyptian (independent) and Western press discourses in their representation of the Egyptian January 25 protests. It also examined reported speech among other textual features. Youssef's (2012) study aimed at exploring the news media frames employed in the news reports and editorials of American (The Washington Post), British (The Telegraph), and Egyptian (Al-Masry Al-Youm and Al-Ahram) newspapers to represent the protestsin light of the protest paradigm which trivializes and demonizes the social movements and their beliefs. It also aimed at exploring how these newspapers identified the characteristics of war and peace journalism and depicted the protesters. The study demonstrated that the national newspapers were more inclined to stress the protesters' acts of violence and depict the protests as economic threat and chaos. The national newspapers were also prone more towards war-reporting, i.e. resorting to victimizing language and using a language of good and bad dichotomous. In contrast, the study pinpointed that the international newspaper shifted away from the protest paradigm and employed peace-reporting, taking the side of the protesters via depicting them positively. Besides, the international newspapers were constant in their coverage during the event and after Mubarak's downfall, whereas the national newspapers 
started to be explicitly positive of the protests and critical of the regime only after the latter's downfall. In fact, Al-Masry AlYoum showed signs of mixed reporting during the event which either disregarded the protests or focused on positively depicting Mubarak's counter protests.

Eissa's (2015) study examined how Egyptian official vs. independent news outlets' different ideologies and political stances, whether pro- or anti-the MB, influenced their representation of the $\mathrm{MB}$ and/or its opposition with regard to some crucial events during Morsi'srule, like the writing of the draft constitution with the accompanying heated discussion about the MB's intentions. Eissa's (2015) study aimed at quantitatively and qualitatively investigating the ideological structures of polarized discourse and hence the establishment of van Dijk's ideological square in the depiction of news actors and events in the news reports of two online news websites representing two different ideologies: Ikhwanweb (the official English mouthpiece of the MB) and Egyptindependent (the liberal opposing viewpoint to the ruling power). The study investigated the two news websites' coverage of three interrelated events: Morsi's issuing of a constitutional declaration on Nov. 22, 2012, the resultant clashes outside the presidential palace on Dec. 5, 2012, and the issuing of the Egyptian controversial draft constitution on Dec. 15, 2012. The study traced thesourcing of the involved social actors. It found that both news outlets established the Us versus Them dichotomy. The study found a diverse representation of the $\mathrm{MB}$ that reflected the examined news outlets' opposing ideologies. It highlighted that each news outlet highly quoted its camp while silencing the other or quoting it to be criticized.

Comparing and contrasting the main findings of the above studies to those of the present study is presented in Section 6 . 


\section{Methodology}

The New York Times (American) and Al-Masry Al-Youm (Egyptian) represent prominent mainstream widely circulated news outlets. That is, they are powerful in setting the tone for reporting in their countries, which may indicate their impact on the readers who consider them sources to derive news from. In fact, premier newspapers, according to Lawrence (2000), provide indications to other news organizations about what is newsworthy; thus, their importance is not only related to their own wide readership but also to their influence on the content of other news media.

An equally important reason for the selection of both newspapers is their political affiliation which allows analyzing news reporting materials on both investigated protests from different ideological perspectives. To explicate, The New York Times' public editor Daniel Okrent (2004), a Democrat, stated that the newspaper has a general liberal bias in political coverage and news coverage of social issues. Such bias emanates from a belief in liberalism which supports the expansion of civil and political rights and liberties (Adams, 2001). The newspaper, moreover, heavily favors Democrats (Ansolabehere, Lessem, \& Snyder, 2004); accordingly, it endorsed Democrat President Obama in his presidential campaign in 2012 (Brennan, 2012). The newspaper is also an example of the elite media outlets, i.e. agenda setting media; these elite media style the content of the mainstream media in ways that meet the interests of the few elite in control of major profitable corporations (Chomsky, 1997).

As for the examined national newspaper, media discourse production in Egypt is bound to social and political restrictions, like the domination of the government or groups close to the government over the media institutions (Alhumaidi, 2013). Besides, the state Supreme Council of Journalism imposes censorship on the state-owned and privately-owned newspapers since it has the authority to suspend or impound any newspaper at any time (Pasha, 2011; Rubin, 2015; Rugh, 2004).Al-Masry 
Al-Youm, first published during Mubarak's era, tried to provide reliable and objective news coverage as well as balanced information and a wide range of opinions; it did not reflect the view(s) of any political party (Arab West Report, 2008). In other words, Al-Masry Al-Youm's coverage was sometimes reliant on criticizing the government, being an independent (privatelyowned) newspaper (Arab West Report, 2008; Cooper, 2008; Elmasry, 2012; Pasha, 2011). Al-Masry Al-Youm also provided a coverage that was very critical of the MB and Morsi during his one-year rule, being then a representative of the liberal media as opposed to the regime's Islamist media (Elmasry\& el-Nawawy, 2014). The Islamist media established by the MB and their Islamist political allies during Morsi's one year in office were playing a similar role to that of the state media during Mubarak's era which lay in defending the ruler and presenting his vision as the ultimate truth (El Issawi, 2014).

The data collected in the present study comprises 32 news reports collected from the online archives of the examined newspapers and divided equally into 16 reports from each newspaper. Eight news reports from each newspaper on each protest are thoroughly examined by including the headlines, lead paragraphs, satellite paragraphs, and wrap-ups in the analysis, i.e. all the sections of a news report (see Appendices A \& B for a detailed description of the examined news reports).Such reports cover both protests from the eruption of each until the downfall of both regimes (more specifically, from Jan. 25 to Feb. 11, 2011; and from Nov. 22, 2012, when Morsi's constitutional declaration was issued and led to the eruption of the first mass protests against his regime, to July 3, 2013). Such duration is enough to make it clear in each newspaper's representation of each protest whether their stances were constant or changed during each and/or immediately after the end of the targeted regime in association with the then dominant power relations.

The 16 selected news reports on each anti-regime protest cover five events representing the frequently reported key events 
during each protest and the main phases in the escalation of each protest. The selection of these key events have been conducted based on scrutinizing the surface of the news reports published on both anti-regime protests in each newspaper via going through the headlines, subhead lines if available, and lead paragraphs in order to find out the most frequent reported topics, which had come up with the bulleted key events below. Furthermore, the selected events that occupied more space in each newspaper than the selected corresponding others, i.e. covered in more than three news reports have been devoted two news reports for analysis. Each two news reports issued with the same date on a given key event are ordered alphabetically as (a) and (b) based on the alphabetical order of their headlines to avoid confusion.

The five crucial selected events during the January 25 protests consist of (see Appendix A):

- The eruption of the protests on Jan. 25.

- The Friday of Anger on Jan. 28 which witnessed violent clashes between the state police and the protesters, resulting in police vacuum and chaos and hence Mubarak's sacking of the cabinet and ordering of a nationwide curfew to save Egypt's stability in his first speech to the nation since the eruption of the protests.

- The Battle of the Camel on Feb. 2 that occurred in Tahrir Square between the pro- and anti-Mubarak protesters after his emotional speech on Feb. 1 when he promised political reforms and appointed Suleiman as vice president but refused to relinquish power.

- The largest million-man protest insisting on Mubarak's departure on Feb. 8 (Day of Egypt's Love) tremendously influenced by a TV emotional interview with released youth activist WaelGhonim.

- Mubarak's resignation and ceding of power to the Supreme Council of the Armed Forces (SCAF) on Feb. 11. 
The five central events selected during the June 30 protests lie in (see Appendix B):

- Morsi's constitutional declaration on Nov. 22, 2012, in which he was criticized for usurping all state powers and thus leading to the eruption of the first mass protests against his regime on Nov. 23.

- The beginning of the rush approval of Egypt's post-January 25 protests controversial draft constitution on Nov. 29, 2012 and Morsi's deciding on Dec. 15 as the date for public referendum on such a constitution. This occurred despite the liberal and secular members' boycotting of the constituent assembly and the continuous anti-declaration and anti-draft constitution mega protests on the part of Morsi's opponents, resulting in many casualties in the first most violent clashes between the anti- and pro-Morsi protesters on Dec. 5.

- The eruption of Tamarrod's planned June 30 million-man protests based on gathering public petitions calling mainly for Morsi's downfall and early presidential elections.

- The military intervention in response to the public's demands via issuing a statement on July 1 giving a 48 -hour time limit for all parties to reach a consensus in an attempt to resolve the internal conflict and meet the people's legitimate demands.

- The military's announcement of a roadmap via a televised speech to the nation on July 3 by which Morsi was ousted, the constitution suspended, and a non-military interim leader appointed.

However, it has to be noted, in the Egyptian newspaper, that the articles reporting on each investigated key event were published the day after the occurrence of such event(s) in contrast to the examined American newspaper whose reports on the same event(s) were published online on the day of 
occurrence. I have translated all the examples taken from the Egyptian newspaper into English, but I have analyzed the Arabic version of the selected examples since the present study focuses on the news produced to the original targeted audience by each examined news outlet. In Section 5, each example or group of examples chosen for analysis on a particular point is immediately preceded by the name of the newspaper from which it is selected. Besides, every example is immediately followed by the full date of the related article between brackets. Moreover, the tokens analyzed are both typed in boldface in each example and written in italics in the in-text analysis.

\section{Analysis and Discussion}

In the investigated news reports on the January 25 and June 30 protests, both examined newspapers structure voices in a way that provides a positive portrayal of the in group and a negative portrayal of the out group according to each newspaper's ideological stance towards the protests. This could be detected in the examples of the antagonist-protagonist structuring of voices in both newspapers that are conducive to one group and/or counter another, as explained in the below three-stage analysis representing Fairclough's (1995a) CDA framework:

\subsection{Description Stage}

\subsubsection{Significant Inclusion and Exclusion of Voices: Primary and Counter Definers}

Reporters include certain voices and they exclude others; they are taught by their media institutions to be selective regarding which elements of an utterance to use as a quote (Cotter, 2010). Such selection contextualizes the quote in a way that can have a serious effect on the meaning of the said (Fairclough, 2003) and hence positions the quoted voice in a manner that throws a positive light on it and the conflicting party it represents and a 
negative light on the opposing party. This helps create the primary and secondary definers of the situation according to each newspaper's definition of the in group and out group.

\subsubsection{Egyptian January 25 Protests}

The New York Times adopts and seeks the definitions of the regime's opponents as opposed to the authority figures and their backers. To illustrate, it quotes the details of the protesting situation and violence committed by the regime to disperse the protests from the anti-regime protesters, and their utterances are not challenged by the newspaper; thus, they are the primary definers. In contrast, the newspaper provides shallow unevidenced statements on the part of the regime's backers praising Mubarak and casts doubt on and downplays the regime's negative depiction of its opponents; that is, they are the counter definers. Consider the examples below:

(1) "We don't know who is with us and who is against us now we are lost," said Abdel Raouf Mohamed, 37, before he was interrupted by a burly young man who shouted: "I love Mubarak! I need Mubarak!"

Seven minutes later, RedaSadak, 45, said, "In 10 minutes, there will be a big fight here - it is an old game, the oldest game in the regime."

In fact, before he finished speaking, rocks and sticks began to fly from the pro-Mubarak forces into the crowd of the antiMubarak demonstrators $(2-2-2011 a)$.

(2) [...] Mr. Mubarak, 82, breaking days of silence, appeared on national television, promising to replace the ministers in his government, but calling popular protests "part of bigger plot to shake the stability" of Egypt. [...]

"I will not shy away from taking any decision that maintains the security of every Egyptian," he vowed, as gunfire rang out around Cairo $(28-1-2011 b)$. 
In (1) the voiced protesters are individualized as Abdel Raouf Mohamed, 37 and RedaSadak, 45, respectively, whereas the voice of the pro-regime protester is depersonalized and referred to by physical appearance as a burly young man. This factualizes the former and dehumanizes the latter, as maintained by Juan (2009), though both are directly quoted. In reference to themselves, the former used the pronoun we, which emphasizes his individualism is meant to symbolize the other members of the group in question, i.e. the anti-regime protesters, as said by Tuchman (1978). Conversely, the pro-Mubarak protester was only expressing himself by using the first person singular pronoun, which, together with the fact that his short statement did not criticize the protesters in any sense, further reduces the importance of his words regarding his love and need for Mubarak. His statement is surrounded by the two quoted protesters' words that negatively depicted the regime's connived violence against them. Such negative image is immediately confirmed by the reporter's description of the aggression initiated by the pro-Mubarak protesters against the anti-Mubarak protesters, which serves to both gain the readers' sympathy for the latter and legitimize their demands.

In (2), Mubarak's depiction of the protests in his address to the people as "part of bigger plot to shake the stability" of the nation is placed in a strategic quotation, which makes the factualness of the said attached to the speaker only and implies the reporter's covert questioning and/or rejection of the president's negative depiction of his opponents' protesting act and the scheme behind it. This, in turn, undermines the positive impression created by the positive declarative reporting verb promising which, in terms of Chen's (2007) positive category of verbal processes, shows the speaker as being powerful and responsible with respect to changing his cabinet as requested by the protesters. The direct quote in the second section of the example increases the readers' 
negative feelings towards the president though it is accompanied by the positive declarative reporting verb vowed which shows him as bound by an oath to protect the Egyptians. Such adverse feelings arise from the dependent clause that immediately follows his speech, describing the sound of gunshot that was spreading in Cairo then. Such clause makes his directly quoted words communicate his intention to take any decision necessary to save the nation in a negative tone since it shows such decision as intended violence to quell the protests being a plot against the nation's interests, and the direct quote expresses such violence as an indisputable fact. This is further emphasized in the same examined report (b) dated Jan. 28 where the scene of his police apparatus' violence against the unarmed protesters was explicitly highlighted and detailed, which refutes Mubarak's promise to protect each Egyptian and displays him as a liar. Accordingly, contextualizing the positive reporting verb and the direct quote in such manner, i.e. the context surrounding the cited statement, frames the readers' understanding of how violent Mubarak could be in confronting the anti-regime protests. This is particularly due to the fact that the first section of the same example, i.e. part of the surrounding context, contains the reporter's overt reference to the anti-regime protests as popular protests, which, in turn, implies that Mubarak's intended violence against them must have been intense enough to enable him to put an end to such public protests.

Unlike the American newspaper's positive representation of the protesters as the primary definers of the protesting situation, Al-Masry Al-Youm undergoes two stages in its representation of the conflicting sides' voices: the pre-Friday of Departure stage on Feb. 4, considered the largest mega protest persistently calling for Mubarak's downfall in response to the Battle of the Camel, and the post-Friday of Departure stage. To explain, in stage one, the newspaper adopts Mubarak's and his supporters' definition of as well as negative evaluation of the anti-regime protests and 
presents them in longer and more vivid quotations dissimilar to the protesters' cited brief and generic anti-regime statements and chants. This makes the former the primary definers and reflects the newspaper's support for them, as apparent in:

(3) وقالت إحدى المشاركات فى مظاهرات التائيد إن الرئيس حقق جميع مطالب المعارضين، وإنها

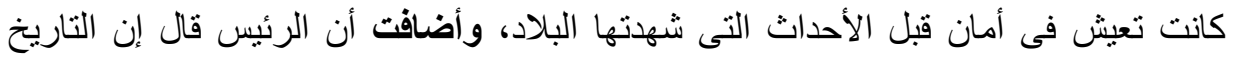

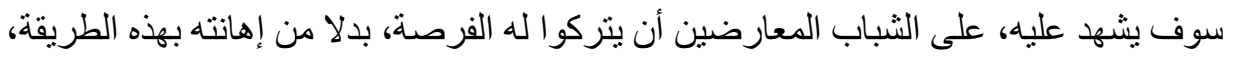

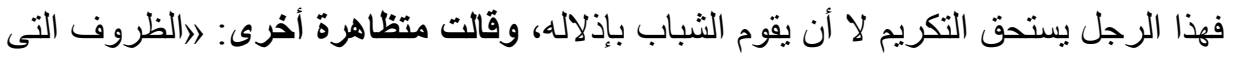

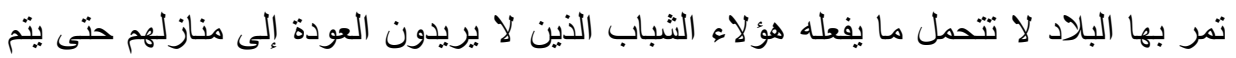

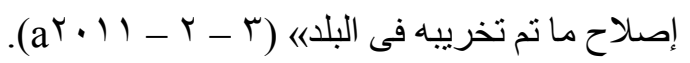

(One of the participants in the supportive protests said that the president had met all the demands of the opposition and that she had been safe before the events witnessed in the country. She added that the president said history will testify to him. Young oppositionists should leave him the opportunity, rather than insult him in this way. This man deserves the honor, not to be humiliated by young people. Another protester said: "The conditions that the country is going through do not bear what is being done by these young people who do not want to return to their homes until the damage caused in the country has been repaired") $(3-2-2011 a)$.

Example (3) keys on the dangers of the anti-regime protests to Egypt and its people from the pro-Mubarak protesters' perspective. Such dangers consisted in threatening the state's stability and safety, causing economic deterioration and general devastation, as well as insulting and humiliating the president at the hands of the few stubborn young opponents remaining in the Square and insisting on his departure even after his Feb. 1 promises of conducting political reforms. Such negative portrayal of the anti-government protests is contrasted with the positive image of both Mubarak as being the achiever of their demands and the rescuer of the nation's safety and the conscious young protesters who responded to his promises by going home. This, in turn, magnifies the image of the pro-regime protesters' rational attitude towards the nation's internal crisis since they are given 
the fortune to express themselves in a way that discolors the behavior and value of the opposing camp, thus giving the impression that sources on its part are unreliable in newsgathering, as argued by van Dijk (1988). In fact, incorporating two unnamed female speakers as belonging to a group like حدى المشاركات في مظاهرات الثأييد/2one of the participants in the supportive protests' and متظاهرة أخرى الخدارك 'another protester' emphasizes the notion of unity and popularity, as stated by Lagonikos (2005). It also enables them, as argued by Tuchman (1978), to symbolize the other members of the group in question, i.e. the pro-Mubarak protesters, and speak up their demands. Quoting more or less the same idea twice: once indirectly and once directly from two different sources serves as a confirmation of their positive evaluation of the president and negative evaluation of the protesters. In the first indirect quotation, the authorial voice seems to be inserted within the supporter's voice as if both shared the same view. The second direct quotation displays that these were truly the indisputable words used by the supporter to express her camp's stance towards the protests and the president, maintaining the boundaries between the authorial voice and the quoted speaker. They all wanted the anti-regime protesters to give Mubarak the chance to achieve his pledges and repair the damages caused by the former across the nation. As observed, the pro-Mubarak camp's demands are not challenged by the opposing camp whose voice is marginalized in association with the Battle of the Camel, as noted in the examined reports on Feb. 2, except for very few projections that are brief and vague, being either chants or mere allegations against the regime of being involved in the violence exercised against them in the Square. This reflects the newspaper's predilection towards the regime's supporting camp.

Al-Masry Al-Youm, in the post-Friday of Departure stage, explicitly starts to adopt the anti-regime protesters' definition of the protesting situation. Accordingly, a different version of the story of the anti-regime protests is provided that foregrounds the 
positive actions of the protesters and the negative actions of the regime but not as overtly symbolized by Mubarak until his last speech to the nation on Feb. 10. View the example below:

$$
\begin{aligned}
& \text { (4) وتو افدآلاف المنظاهرين من محافظات البحيرة والقليوبية والإسماعيلية والغربية والثرقية، }
\end{aligned}
$$

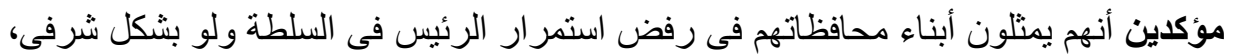

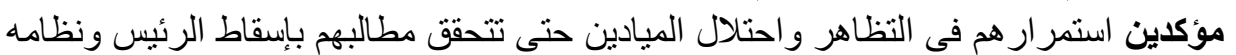

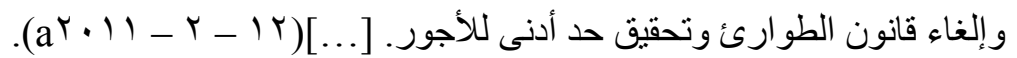

(Thousands of protesters came from the provinces of ElBeheira, Qaliubiya, Ismailia, Gharbia and Sharqiya, asserting that they represent the inhabitants of their provinces with respect to rejecting the continuation of the president in power, even as an honorary president. They also asserted their continued protesting and occupation of the squares until achieving their demands of the downfall of the President and his regime, the abolition of the emergency law, and the guarantee of minimum wages $[\ldots])(12-2-2011 \mathrm{a})$.

Example (4) represents a full detailed statement by an unnamed collective source, namely, thousands of protesters from various governorates, which reflects their power as well as representativeness and hence yields their words valid and reliable. The speakers in (4)deliver a contextual background of the protests through their description of the social injustice that many Egyptians suffered from with respect to two particular issues: the distribution of wealth, specifically governmental salaries as well as the use of the emergency law. Such unfair and inhumane life conditions exhibit the distress and hardship the Egyptians were going through under Mubarak's regime, which stirs the readers' anger against the latter and compassion for the former. Such contextual details are totally absent from the reported speech of the sources on the regime's side, i.e. absent news, as is called by Eissa (2015), which leads to creating a contradictory image of the conflicting parties towards the fall of the regime that deviates from their image before the Friday of Departure on Feb. 4. The indirect quotation is reported using the adverb مؤكدين 'asserting' twice derived from the verbal process 
يؤكد 'assert' which represents one of Chen's (2007) positive authoritative reporting verbs.It displays the protesters as being powerful and influential with respect to their being representatives of the insistence of their governorates' inhabitants on ousting Mubarak, lifting the emergency law, and deciding on a minimum wage rate to ensure a dignified life. The protesters' reported statement is preceded and followed in the investigated report (a) dated Feb. 11 by other protesters' statements that repeat their main demand of Mubarak's downfall in addition to other demands lying in achieving social equality and pursuing the corruptors, which denigrates Mubarak and his autocratic regime and venerates the protesters as seekers of democracy and justice. In fact, it is unlikely that the protesters named their remaining in the squares across Egypt as حتلال/ 'occupation'. By choosing indirect reporting, the reporter is able to modify the text in such a way that it becomes in favor of the protesters. Such word indicates both the huge number of the protesters who were seeking freedom and equality and their persistence in getting their demand carried out without ascribing violence to them, which evinces that they had a fair cause and thus magnifies their positive image.

\subsubsection{Egyptian June 30 Protests}

In The New York Times, when the anti-regime protesters are cited, they appear contrasted with the regime's voice, making the former's alternative view seem irrational and illegitimate, as argued by Hertog and Mcleod (1995). In other words, in contrast to the newspaper's representation of voices in its coverage of the January 25 protests, it presents the regime and its backers as the primary definers of the situation. To exemplify, the newspaper adopts the regime's positive perspective towards the presidential decrees as a path to democracy, whereas the newspaper depicts the regime's opposition as deliberate usurpers of power from a legitimate regime. Think over the following examples:

(5) Since Thursday, when Mr. Morsi issued the decree, the president and his supporters have argued that he acted 
precisely to gain the power to address the complaints of his critics, including the families of protesters killed during the uprising and its aftermath $(23-11-2012)$.

(6) Many vowed to stay in the streets until Mr. Morsi resigned. Some joked that it should be comparatively easy: just two years ago, Egyptian protesters toppled a more powerful president, even though he controlled a fearsome police state.But there is no legal mechanism to remove Mr. Morsi until the election of a new Parliament, expected later this year, $[\ldots]$.

[...] and even some critics acknowledge that forcing the first democratically elected president from power would set a precedent for future instability $(30-6-2013)$.

The newspaper, as displayed in the indirect quote in (5), eliminates the boundaries between the regime's reported voice, namely, the president and his supporters, and the authorial voice. The speakers attempt to pinpoint the reason behind issuing Morsi's constitutional declaration as being a tool that could enable Morsi to gain the power needed to satisfy his people's demands, such as the retrial of those responsible for killing protesters during and after the anti-Mubarak protests. The reporting verb argued is one of Chen's (2007) positive exhortative verbal processes creating the impression that the speakers were people of wisdom who do not have the power to force others to do what they want. This indicates that Morsi and his backers were well-intentioned with respect to the declaration but were not dominant enough to impose their view on their critics. In other words, they did not intend to use violence with their opponents to implement the presidential decree, and the use of the present perfect tense in the formation of the reporting verb shows the regime's repeated and continuous attempts to explain the president's declaration and convince their opponents of its urgency. Besides, depicting the president as lacking enough 
power to meet his people's needs, as embodied in the verb phrase acted to gain the power, implies that Morsi's authority as the leader of the country was not enough to carry out the demands of his people. It also indicates that other forces, such as the judiciary from which he wanted to immunize his edicts, were powerful enough to challenge his presidential will in this respect. This, in sequence, arouses the readers' sympathy with Morsi and anger against such forces intriguing against the regime (see the examined reports dated Nov. 22, 23 29, \& Dec. 5).

The anti-Morsi protesters, as noted in (6), are reported using Chen's (2007) positive declarative verbal process vowed which shows them as being powerful enough to carry out their action lying in their defiance to the regime until Morsi leaves office, especially that his regime was not as powerful and brutal as that of the toppled Mubarak. This, in turn, displays Morsi in a positive light since leading a fierce police state was only linked to Mubarak in the comparison drawn between both presidents in the speaker's words. To put it more pointedly, Morsi's regime was not practicing violence against its opponents. Accordingly, the powerful image of the protesters who drew such comparison is de-emphasized. Such devaluation is magnified by the reporter's extra information regarding the illegality of Morsi's removal since no elected parliament was then available, which delegitimizes the protesters' persistent demand of Morsi's departure. What further supports the reporter's perspective is the admission of some of the regime's critics, i.e. opponents, that the ouster of democratically elected Morsi as such would cause instability in the future of the Egyptian authority. Voicing some of Morsi's critics, i.e. sources from the enemy side speaking against their men's intended action to remove Morsi from power in addition to reporting them using Chen's (2005) negative verbal processes acknowledgedtotally distorts the aforementioned powerful image of the protesters. Such reporting verb indicates the speaker's realization and recognition of the negative impact of the protester's removal of Morsi. This representation turns them to appear as mere usurpers of power and hence lets Morsi's regime gain the readers' compassion and advocacy. 
Contrary to the examined international newspaper, $\mathrm{Al}$ Masry Al-Youm adopts the anti-regime protesters' ascription of the revolutionary legitimacy to their public will in the face of Morsi's regime. The newspaper foregrounds the anti-regime protesters' detailed comments on the adverse impact of Morsi's declaration on the nation in addition to their intentionally nonviolent tangible reaction to it. This displays them as the main definers. In contrast, the newspaper provides a challenged representation of the regime's voice and its supporters' as well defending the declaration, which indicates the newspaper's predilection towards the stance of the opposing camp. See the examples below:

(7) ووصف الدكتور طارق السهرى، عضو الهيئة العليا لحزب النور، قرارات (الهرسى) بأنها

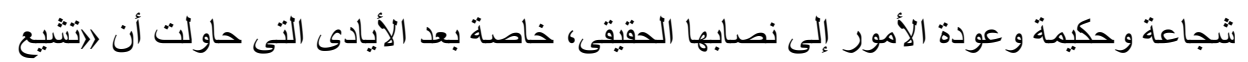
الفوضى فى البلادن).

وأيدت جماعة الإخوان المسلمينالقرارات التى وصفتها ب-رالثورية) للرئيس، مؤكدة

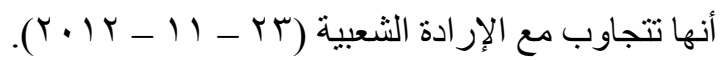

(Dr. Tarek El-Sehry, a member of the supreme committee of El-Nour party, described "Morsi's" decisions as courageous and wise and the return of things to the right way, especially after the hands that tried to "create chaos in the country."

The MB supported the president's decisions it described as "revolutionary", asserting that they are responsive to the public will) $(23-11-2012)$.

(8) وقالت القوى الوطنية فى بيان أصدرته، أمس، إن خروج المصريين يوم الثلاثاء الماضى

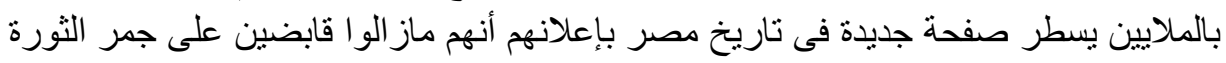

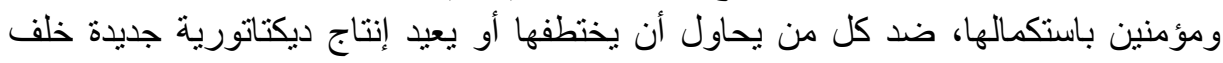

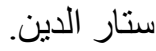
[...] أعضاء جماعة الإخوان المسلمين، الذين قال البيان عنهم إنهم فقدوا أبسط قواعد المسؤولية

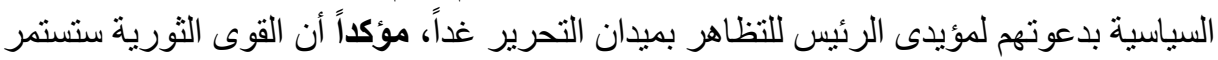

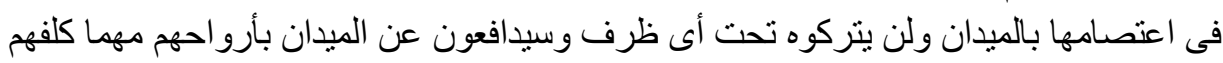

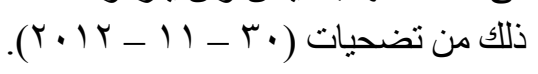

(In a statement issued yesterday, the national forces said that the Egyptians' taking to the streets in millions last Tuesday 
writes a new page in Egypt's history by announcing that they are still grasping the embers of the revolution and believing in completing it against anyone trying to steal it or reproduce a new dictatorship under the guise of religion.

And the members of the MB, about whom the statement said that they have lost the most basic rules of political responsibility by calling the supporters of the President to demonstrate in Tahrir Square tomorrow, asserting that the revolutionary forces will continue to their sit in in the Square and will not leave under any circumstances and will defend it with their lives, whatever sacrifices they make) $(30-11-2012)$.

As observed in (7), the regime's Islamist supporter Dr. Tarek El-Sehry, a member of the supreme committee of El-Nour party, depicted Morsi positively as being sensible and powerful as to his declaration being a response to the unknown people's chaotic acts across the nation. Such unclear reason is quoted by the reporter using a strategic quotation, which reflects his attempt to distance himself from the truth claim of the speaker's expression. The same occurs with the MB's strategically quoted description of Morsi's declaration as being revolutionary. This casts doubt on the factualness of both expressions and draws the readers' attention more to the formulation of the quoted utterances than the content. In fact, stirring the readers' doubt about El-Sehry's explanation of the reason behind the declaration undermines his positive depiction of such declaration as being wise in the first place. In the same vein, the reporter's distancing himself from the presupposition of the MB's positive depiction of the declaration implicitly negates its correspondence to the public's will despite the use of the adverb مؤكدة 'asserting' derived from Chen's (2007) positive authoritative verbal process 5 /asserted' in quoting the MB being a dominant political force then. Both utterances are backgrounded in the second half of the examined report dated Nov. 23, while the negative depiction of the declaration by the regime's opponents is foregrounded in both the lead paragraph and first half of the report, and they are more frequently reported there 
both directly and indirectly than the regime and its proponents (17 to 8). This, in turn, unveils the newspaper's bias towards the regime's opponents from the very onset of its coverage of the protests via playing down the importance of the speech and perspective of the regime's backers.

As apparent in (8), the contrast between both conflicting sides is explicitly drawn through the anti-regime national forces' words in their statement issued on Nov. 29. They positively made reference to the popularity and massiveness of the anti-Morsi extra-legal declaration protests on Nov. 27 involving not only political and revolutionary forces but also the Egyptian public. In addition, they linked their protesting act to Egypt's history in a manner that reveals how patriotic, powerful, and influential such protests were, which credits them and their demands. Moreover, describing themselves as being the protectors of the January 25 revolution reflects their persistence in achieving democracy and yields a justification for their protests against Morsi and his Islamist allies since the latter were seeking to create a new totalitarian regime due to their attempt to solely control Egypt's political scene, as stated in the examined report dated Nov. 30. The quoted statement, furthermore, adversely portrayed the MB in particular as being politically irresponsible owing to their call for a pro-Morsi protest in Tharir Square where the anti-Morsi forces had their sit-in, which might cause clashes between both camps. This, in turn, worsens the negative image of Morsi's regime as opposed to the sit-in protesters whose persistent defense of the Square to the death demonstrates that they were expected to be exposed to great danger at the hands of Morsi's supporters. This displays the former as the potential victims and the latter as the potential victimizers. The reporter's use of the adverb مؤكداasserting' derived from Chen's (2007) positive authoritative verbal process أكد' 'asserted' renders the national forces and their statement powerful and influential. That is, they are presented in a positive light as being much more responsible than the MB and Morsi's backers, which stirs the readers' support 
for the former, especially that no violence is indicated on their part despite their massive protests. In fact, because the words of the anti-Morsi national forces are indirectly reported, the newspaper's authorial voice and hence perspective cannot be distinguished from the original speaker's since indirect quotation is ambivalent about the actual words that were said. This exhibits the newspaper's endorsement of the anti-regime protesters.

\subsubsection{Texturing of Voices in Relation to Each Other}

Fairlcough (2003) has pointed out the importance of addressing how a quote figures in a text since the context in which a source is reported serves an interpretation that is favorable or unfavorable of a particular social actor. Such context could lie in the integration of a voice whether belonging to the conflicting parties or other neutral sources to form the basis for a statement made by any of the conflicting parties so as to vilify or endorse such statement according to the newspaper's stance towards this particular conflicting party.

\subsubsection{Egyptian January 25 Protests}

A closer investigation of the employed sources in The New York Times shows how they are positioned in the nearest context in a manner that displays the protesters positively and the regime adversely, as seen in:

(9) The independent group Human Rights Watch said that it had confirmed more than 300 fatalities during the protests by visiting hospitals in a few Egyptian cities. "The government wanted to say that life was returning to normal," said Mahmoud Mustafa, a 25-year-old protester standing in front of Parliament. "We're saying it's not" $(8-2-2011)$.

It is obvious in (9) that the international credible independent group Human Rights Watch gives insight into the sorry state of the anti-regime protests through underscoring 300 deaths on their part by visiting hospitals in some governorates. This hints at the possibility that such a number could increase if 
more governorates were included. Following the neutral voice is the voice of a 25-year old protester called Mohamed Mostafa who confirmed, in the name of all the protesters, that the government wrongly thought that the nation's internal situation could be eased after the fall of many victims on the former's part. In other words, the statement of the Human Rights Watch acts as a justification for the protesters' insistence on continuing their act against the regime and indicates that the casualties were only on their side, which legitimizes their defiance in the face of the brutal regime. Thus, it can be said that the relationship between both quoted voices is not arbitrary in the sense that the statement of the protester is strengthened by the information given by the neutral voice.

Despite the fact that Al-Masry Al-Youm, on the face of it, reports the anti-regime protesters along with the regime before the Friday of Departure on Feb. 4, their voice is contextualized in a way that derives an interpretation favorable of the regime and his proponents. In the newspaper's post-Feb. 4 coverage, the protesters' voice is maximally prevalent in the newspaper's coverage as opposed to the regime's and favorably positioned. Consider the examples below:

(10)واتهم المحتجون على نظام مبارك الحكومة ونواب ينتمون للحزب الوطنى، بترتيب

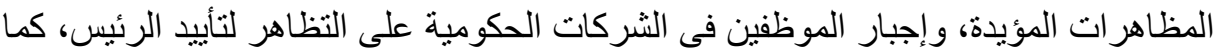

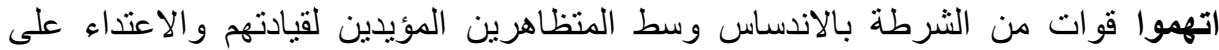

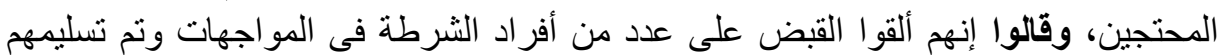

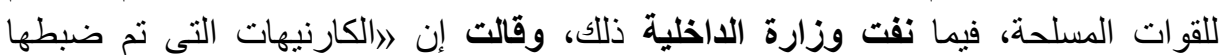

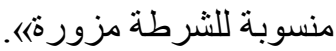

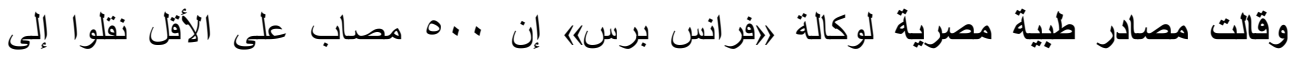

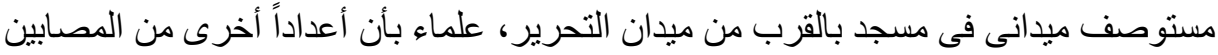
كانو ا نقلو ا إلى عدة مسنشفيات. وقالت الوكالة إن قنابل مسيلة للاموع أطلقت على المنظظاهرين المعارضين للرئيس مبارك فى ميدان

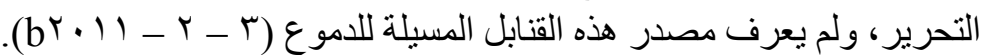

(Opponents to Mubarak's regime accused the government and MPs belonging to the NDP of coordinating the supportive protests and forcing the employees of governmental companies 
to demonstrate in support of the president. They also accused police forces of infiltrating among the protesters supporting their leadership and assaulting the opponents. They said they arrested a number of police officers in the clashes and handed them over to the armed forces, while the Ministry of the Interior denied it and said that «the identification cards that were seized attributed to the police are forged».

Egyptian medical sources told France-Press Agency that at least 500 injuries were taken to a field clinic in a mosque near Tahrir Square and that other numbers of injuries were taken to several hospitals.

The agency said that tear gas canisters were fired at antiPresident Mubarak protesters in Tahrir Square, and the source of such canisters was not known) (3-2-2011b).

(11)وظهرت فى المسيرة المليونية الثالثة، ولأول مرة، الداعية الإسلامية الدكتورة ملكة زرار،

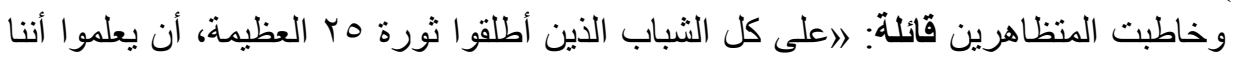



$$
\text { أن نصمد ونصبر حتى ننتصره). }
$$

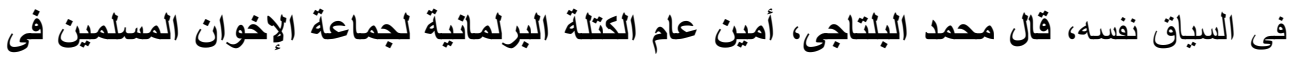

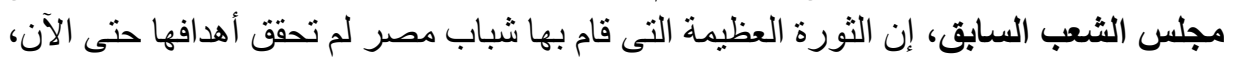

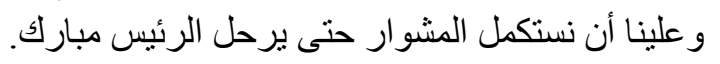

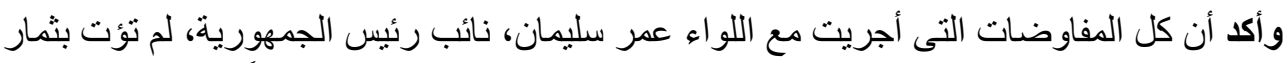

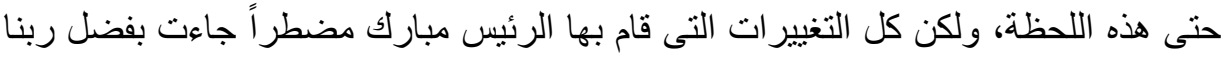

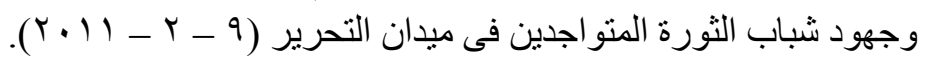

(For the first time, Muslim preacher Dr. MalakaZarrar appeared in the third million-man protest and addressed the protesters, saying:"All the young people who launched the great revolution of January 25 should know that we are in front of a stubborn, mean, and cunning regime that tries to abort the revolution, so that it can come back and eat our flesh again. We must resist and wait until we win."

In the same context, Mohamed EIBeltagy, secretary-general of the parliamentary bloc of the MB in the former People's 
Assembly, said that the great revolution carried out by the youth of Egypt has not achieved its goals yet, and we must continue the journey until President Mubarak leaves.

He asserted that all the negotiations conducted with Major General Omar Suleiman, Vice President of the Republic, had not borne fruit until that moment. But all the changes made by President Mubarak were forced by the help of God and the efforts of the revolutionary youth present in Tahrir Square) (9-2 -2011).

As displayed in example (10), the protesters accused the government and NDP, not Mubarak of coordinating the proregime protests and accused some police forces of infiltrating into such protests to lead Mubarak's proponents to assault the former. The reporter's repeated use of the reporting verb تهمو اتهويو/accused' in citing the protesters indicates that he takes distance from their speech, as held by van Dijk (1993a). Such accusation was also negated by the Interior Ministry whose denial is placed in the same line with the protesters' accusation and directly quoted; that is, the reporter takes distance from its statement as well. This puts both voices on an equal footing since none of their statements is adopted by the authorial voice and hence reporting appears to be not prejudicial. This copes with the newspaper's coveragein stage one where it focuses on the violent clashes between the protesters and police, with the latter depicted as the instigators of violence and the former as causes of chaos in response. However, the reported utterances here are followed by two quotes by Egyptian medical sources and the international media source France Press, i.e. neutral voices that did not ascribe any violent act committed against the protesters to Mubarak's supporters. To expound, the cited medical sources spoke generally of more than 500 injuries but did not specify whether they belonged to the pro- or anti-Mubarak protesters and the news agency stated that the latter were hit by tear gas canisters but the agent remained unknown. This underpins that perhaps the 
police did it since they had already done it before, as described in the examined report (b) dated Feb. 29 or maybe a third party instigated such vicious attacks on the protesters in an attempt to incite them against the state, as stated in the examined reports on Feb. 2. Such contextualization of the above quotes augments Mubarak's and his backers' positive image and evokes the readers' both support for Mubarak's decision to remain in office until he finishes his term and sympathy for the victims on the pro-and anti-Mubarak protesters' sides.

Example (11), in contrast, overtly sheds a positive light on the anti-regime protesters through the quoted words of two participants in the protests: well-known Islamic preacher Dr. MalakaZarrar and former MB parliamentary member Mohamed ElBeltagy. Both depict the protesting act as a great revolution staged by the young Egyptians. The regime, on the contrary, is represented in a negative tone by pinpointing its obstinate and cunning attempt to abort the revolution and the protesters' insistence on Mubarak's departure, their unfruitful negotiations with Suleiman, as well as their ability to force Mubarak to conduct particular changes during their protesting act. Zarrar's words are directly quoted, which makes them seem factual and therefore influential, and ElBeltagy's words are reported using Chen's (2007) positive authoritative verb أكد 'asserted' which further reflects his power and influence, being one of the protesters. Actually, the adverse image of Mubarak and his regime's men in both speakers' utterances is far more spotlighted via the favorable depiction of his opponents as being mainly revolutionary young men, i.e. devoid of political agendas and powerfully enthusiastic but peaceful. They both succeeded to push Mubarak to meet some of their demands and were involved in negotiations with the regime in a bid to achieve the rest of their aims, but when such negotiations failed, they insisted on his downfall. In the examined report on Feb. 8 million-man protest, only the voices quoted are those of the protesters, and any quote is followed and preceded by other utterances, similar to the 
analyzed voices of Zarrar and ElBeltagy, that also positively portray the protests as a great revolution and underscore Mubarak's departure as salvation for the Egyptians. That is, all their quotes frame each other by working as a sort of confirmation of such portrayal, which stimulates the readers' support for the anti-regime protests.

\subsubsection{Egyptian June 30 Protests}

The New York Times employs neutral sources that either frame or are framed by sources belonging to both the regime and its opponents in a manner that generates a positive impression about the former contrary to the newspaper's negative depiction of Mubarak's regime. In example (12) below, the newspaper gives little weight to the negative impact of the regime's decrees by refuting the opposition's criticism of such decrees:

(12)[...] One representative said the constitution represented only the Islamists who had drafted it. "Not the constitution of Egypt," the church negotiator, KamelSaleh, told the state newspaper Al Ahram.

But several independent analysts said the hasty way in which it was prepared led to more problems than any ideological agenda. Instead of starting from scratch and drawing on the lessons of other countries, the deadline-conscious drafters tinkered with Egypt's existing Constitution, without attempting to radically remake Egyptian law in any particular direction, said Ziad al-Ali, who has tracked the assembly for the International Institute for Democratic and Electoral Assistance, an intergovernmental organization in Sweden $(29-11$ - 2012).

In (12), the Islamists drafters of the constitution were denied any ideological agenda behind their work by a credible and expert neutral source, namely, several independent analysts, one of whom is Ziad al-Ali working for the International Institute for 
Democratic and Electoral Assistance, an intergovernmental organization in Sweden. The words of the named source get support from the undefined number of unnamed sources who are assumed to be equal in rank, as put by Stenvall (2008). They explained that the assembly members' rapid preparation of the draft constitution was the real problem and there was no attempt on their part to Islamize it. Stenvall (2008) maintained that analysts are esteemed news actors in their own right and often used to bring forward a contrasting view. Because such evaluation of the drafters and the charter is quoted from an impartial source who also has a professional fair vision, the readers were more likely to accept it, as stated by van Dijk (2001), due to its being much more credible than the authority. That is, the official voice, as taken for granted by the readers, is in direct relation with its interests. Accordingly, the neutral voice's speech negatively frames the statement of the regime's opposition representative in the constituent assembly KamelSaleh, the church negotiator, by means of nullifying the validity of his assumption that the charter represented only the Islamists, not all Egyptians. In other words, the relationship between both voices is not random since the statement of the opposition source is weakened by the statement of the knowledgeable neutral source, which devalues the former's negative portrayal of the regime and Islamists in power and reflects the newspaper's predilection towards the latter.

Similar to the international newspaper at hand, Al-Masry AlYoum positions sources whether belonging to the conflicting parties or neutral others as groundwork for the utterances of the former. However, different from the international newspaper, such voices are aimed to derive an interpretation favorable of the anti-regime protesters and unfavorable of Morsi and his government. In the following example, the national newspaper 
attempts to pinpoint the protesters' intended peacefulness in conducting their anti-Morsi protests:

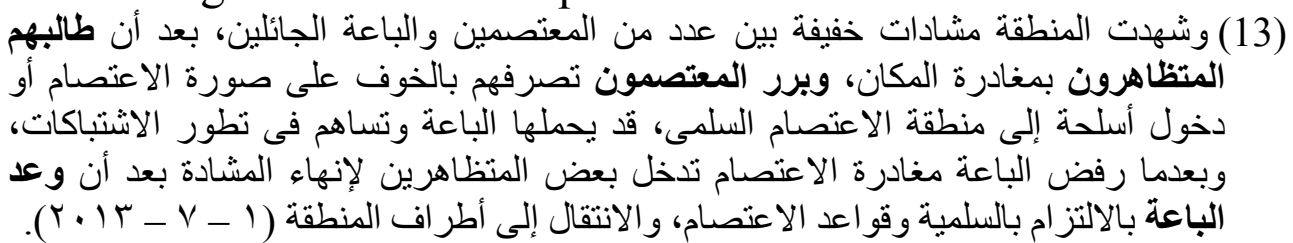

(The area witnessed minor clashes between a number of protesters and street vendors after the protesters demanded them to leave the place. The protesters justified their behavior due to their fear for the image of the sit-in or the entry of weapons to the peaceful sit-in area which could be carried by the vendors and contribute to the development of clashes. After the vendors refused to leave the sit-in, some protesters intervened to end the quarrel whenthe former promised to abide by peacefulness and the rules of sit-in and to move to the outskirts of the area) $(1-7-2013)$.

The reported exchanges of both the protesters and street vendors in (13) sheds light on the former's inherent non-violent attitude and their insistence on keeping their protests and sit-ins peaceful by asking the latter to abide by their rules so as to avoid the occurrence of any armed clashes. The voice of the street vendors, i.e. a neutral voice, rejecting to leave the sit-in area and eventually promising to comply with the instructions of the sit-in protesters enhances the positive image of the latter. It also underpins their powerfulness and influence in spite of not being coercers as well as their rationality, as manifested in the reporter's use of Chen's (2007) positive authoritative and informative reporting verbs طالبهم 'demanded' and برر 'justified', respectively. Actually, such an incident is absent from the international newspaper's coverage of the June 30 protests, perhaps for it portrays the protesters positively and hints at an anticipated danger at the hands of the regime's camp that might lead to the acceleration of clashes between both sides This, in turn, presents the regime negatively. 


\subsubsection{Implemented Voices in the Wrap-up}

The wrap-up of the report is an eminent position (Fairclough, 2003); it can encompass the voice of any of the conflicting sides, not only the primary definer. However, these voices are specifically included in such position to underscore the authorial voice's stance to the advantage of or against a particular side. Quotations of any type there, in fact, represent the critical stance of the newspaper and the party it sides with or against (Fairclough, 2003; van Ginneken, 2002). Hence, it is more significant to shed light on the final voices implemented in the wrap-up and its relevance in this respect than the initial voices employed in the headline, the lead paragraph, and/or the first section of the report.

\subsubsection{Egyptian January 25 Protests}

It can be seen in The New York Times' eight analyzed reports that the government's voice is mentioned only once in the wrap-up and in combination with a voice on the protesters' side. The rest of the wrapups are dedicated to speaking positively of the protesters and/or negatively of the regime via sources on the former's side (5 times) and neutral sources ( 2 times). Examine the following example:

(14) Several others said they felt shame that their homeland - the cradle of civilization and a onetime leader of the Arab world - had slipped toward backwardness and irrelevance, eclipsed by the rise of the Persian Gulf states. Some said they felt outdone by tiny Tunisia. Mohamed Fouad, sitting near the Ramses Hilton nursing a wound from a rubber-coated bullet in the middle of his forehead, wondered how long it would take to dislodge Mr. Mubarak. "In Tunis, they protested for a month," he said. "But they have 11 million people. We have 85 million" (28-1-2011b).

Several protesters are quoted in (14) grieving the social and economic collapse of Egypt under Mubarak's rule compared to the now advanced Arab Gulf states. However, one cannot tell whether the hyphenated phrase describing Egypt as the cradle of 
civilization and a onetime leader of the Arab world is the speaker's or the reporter's since the protesters are indirectly quoted. This deforms the image of the regime and hence draws the readers' sympathy for the protesters. Such a negative image of the Egyptian state is enlarged by the depiction of the wounded protester Mohamed Fouad who was hit by a rubber bullet in his forehead, i.e. a victim of violence. He is cited drawing a comparison between Tunisia whose authoritarian leader had been dislodged in a month time by its tiny population and Egypt whose leader was being sought to be ousted by its very much huge population exceeding the former almost eight times. Hence, his ouster should take less time. Such a comparison is repeated twice in the wrap-up, which indicates that both protesting acts were alike as to being popular moves against despotic leaders. The newspaper, from the very first moment of its coverage of the anti-regime protests in Egypt, portrays them as being inspired by the protests against the authoritarian government in Tunisia, as stated in the examined report dated Jan. 25. Ending the wrap-up with Fouad's statement also stresses the protesters insistence on Mubarak's downfall, and such insistence is actually justified through their grief over the nation's deterioration due to the totalitarianism they were surviving in Mubarak's Egypt similar to that toppled in Tunisia. In fact, though Mubarak is cited first in the headline and first satellite paragraph of the same analyzed report, it is pictured in a negative tone in both. The newspaper foregrounds both the adverse depiction of his order of a curfew as a crackdown to save his authoritarian regime of nearly 30 year in the headline and lead paragraph and his strategically quoted depiction of the huge angry mass protests as a conspiracy against the nation's stability in the first satellite paragraph. Such unfavorable portrayal of Mubarak's voice further adds to the readers' compassion for the protesters and legitimizes their demands, particularly their demand of toppling down the president. 
Al-Masry Al-Youm, in its pre-Feb. 4 coverage, does not voice any of the conflicting sides in the wrap-ups of the reports at issue. Rather, the authorial voice focuses on negatively describing the violent clashes initiated by the state police against the protesters and the latter's anarchy and destruction of private and public properties in reaction to the former. In the newspaper's post-Feb. 4 coverage, the wrap-ups are devoted to speaking positively of the protesters and negatively of the regime via sources on the protesters' part (2 times) and neutral sources (1 time), as patent in:

(15) [...]وأكل عدد من المحامين المثاركين فى المسيرة ثقتهم فى القوات المسلحة لحماية

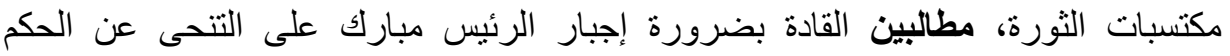

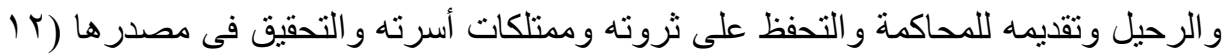

. (a r. $11-r-$

\section{([...] a number of lawyers participating in the march asserted}

their confidence in the armed forces to protect the gains of the revolution, demanding the leaders to force President Mubarak to step down and leave, bring him to trial, and reserve his wealth and his family's property and investigate its source) $(12-2-2011 a)$.

In (15), a number of protesting lawyers are quoted concentering on the gains of the revolution and the patriotic role of the Egyptian army in defending such gains, and no violent acts are linked with their march. Using Chen's (2007) positive authoritative reporting verb كطالبين Sasserted' and the adverb 'demanding' derived from the positive authoritative verbal process طالب 'demanded' reveals the strong bond between the public protesters and the army and the former's great influence on the latter, accordingly. Besides, both verbal processes reflect the protesters' power at that moment very close to their victory over Mubarak. Asking the army to oust Mubarak and put him on trial, sequestrate his assets and his family's as well, and inquire into their wealth further reinforces the negative representation of the corrupt Mubarak and ratifies the protests' demands, specifically Mubarak's departure. Such negative representation of the regime corresponds to that in the lead paragraph of the same analyzed 
report (a) dated Feb. 12 where Mubarak is quoted first via his announcement of delegating power to Suleiman. His address is described as being rejected by millions of citizens who took to the streets in objection to it, which discloses the public's great enmity towards the ruler of the country, hence stimulating the readers' support for the public's demands and actions.

\subsubsection{Egyptian June 30 Protests}

In The New York Times' investigated reports on the June 30 protests, it can be noted that the authorial voice is available solely once justifying the Islamist-dominated assembly's rush approval of the draft charter due to the supreme constitutional court's expected issuing of a ruling to dissolve the assembly. Just overt justification in the reporter's voice in the wrap-up of the report dated Nov. 29 reveals his leaning towards the assembly's act. The rest of the wrap-ups are devoted to positively representing Morsi's regime and its proponents and/or negatively depicting its opponents via sources on the former's part (4 times) and neutral sources ( 3 times). That is, the voice of the opposition is totally absent from the wrap-ups. View the following example: (16) The attackers used green pen lasers to search for figures at the windows of the Brotherhood offices, then hurled Molotov cocktails. They vowed to show no mercy on the members inside. "Their leaders have left them like sheep for the slaughter," one said. Two people were killed in the violence at the headquarters, medics there said.

Thousands of Mr. Morsi's supporters in the Muslim Brotherhood had gathered at a rally near the presidential palace to prepare to defend it if the protesters tried to attack. Many brought batons, pipes, bats, hard hats or motorcycle helmets, even woks or scraps of metal to use as shields. They stood at attention with clubs raised and marched together. "We will sacrifice our lives for our religion," some chanted. "Morsi's men are everywhere" (30-6-2013). 
In the wrap-up in (16), the readers' compassion for the regime's supporters is stimulated through depicting the quoted sources on the anti-regime protesters' part as aggressors as seen in their cited utterance. To explicate, they are portrayed as being intentionally unmerciful towards Morsi's backers in their assault on the MB's headquarters in Cairo on June 30, as evincible in the reporting verb vowed. Such verb, despite being a positive declarative verbal process revealing the seriousness, confidence, power, and assertion of the speaker, it gains a negative sense instead because of being used to report the speaker's unjustified violent attitude towards the MB members inside the building. Hence, it reflects the protesters' forcefulness in conducting such negative behavior. The adverse impact of their brutality, which lay in two killings, is immediately stated by a neutral voice, namely, medics. This arouses the readers' wrath against the protesters', i.e. the victimizers, for most probably those killed belonged to the attacked $\mathrm{MB}$ members, i.e. the victimized since it was not specified by the speaker to which camp the deaths belonged. This is further asserted in the reporter's description of the peaceful reaction of the regime's proponents at a rally near the presidential palace, which highlights them as only defenders of it along with their religion against any attack by the regime's rivals, using domestic tools as shields, as explained by the reporter. In other words, they were only recipients of aggression and intended no harm to others. Such contrast in the attitude of both parties is manifested in the directly quoted words of each which unquestionably represent the protesters as slaughterers and the regime's supporters as scarificers of their own lives. This worsens the negative image of the former and hence devalues their extreme anger at the MB's political dominance which was not linked to violence of any kind. This is described by the authorial voice in both the lead paragraph of the examined report and the eighth satellite paragraph where the anti-regime protesters are quoted for the first time in the report. Though the regime is quoted next in the eighth satellite paragraph through a spokesman for Morsi, his words revolved around a peaceful call 
for a dialogue with the opposition about their demands.It reflects the former's understanding and flexibility in dealing with the crisis and hence delegitimizes the latter's instigated violence against the regime's backers, as presented in the wrap-up and throughout the whole examined report dated June 30. This, in turn, demonstrates the newspaper's support for the regime.

The wrap-ups in Al-Masry Al-Youm key on casting a positive light on the protesters and/or a negative light on the regime via the authorial voice's narration of some incidents (3 times) and the words of the protesters (3 times). Although the MB's voice is presented twice in the wrap-ups praising Morsi and his decrees, it is accompanied by the voice of the regime's opponents condemning the president's decrees and his Islamist regime. This, in turn, challenges the MB's praise and hence downplays its potential favorable effect on the readers. Think over the example below:

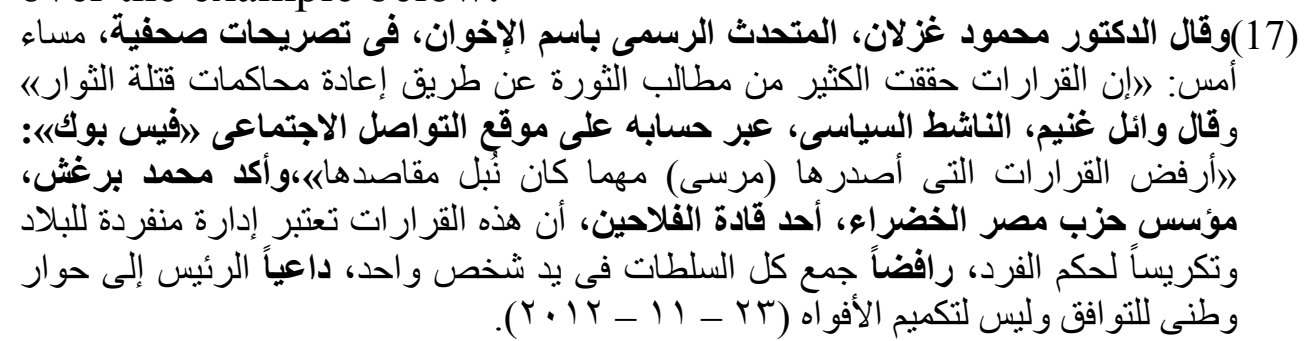

(Dr. Mahmoud Ghozlan, the official spokesman of the MB, said in a press statement yesterday evening: "The decisions have achieved many of the demands of the revolution through the retrial of the killers of the revolutionists." WaelGhonim, a political activist, said through his account on the Facebook: "I reject the decisions issued by (Morsi) whatever the nobility of its purposes». And Mohammed Bargash Founder of the Green Egypt Party and one of the peasants' leadersasserted that these decrees are considered a single administration of the country and dedication to the rule of the individual, rejecting to collect all authorites in the hands of one person and calling the President for a national dialogue for reconciliation not gagging) $(23-11-2012)$. 
As evincible in the wrap-up in (17), one voice on the part of the regime is quoted in the face of two voices on the part of the regime's opponents, which makes the latter's perspective prevail over the former, especially that the wrap-up ends with the latter's. Therefore, their negative evaluation of Morsi's constitutional edicts remains longer in the readers' mind. Besides, the quoted voice on the regime's part is defined as a spokesman for the MB named Dr. Mahmoud Ghozlan as opposed to the more publically selected sources representing the opposition. In other words, WaelGhonim is represented as a political activist without specifying a certain political group or party or even an age group to which he belonged, and Mohammed Bargash is represented not only as the Founder of the Green Egypt party but also as one of the peasants' leaders. That is, he was speaking on behalf of such a popular and sizable category of the Egyptian society. This makes the speech of the opposition's cited voices much more influential than that of the MB's cited voice. Moreover, Ghozlan's words about the positive result of Morsi's declaration with regard to the retrial of those who caused the killing of Egypt's revolutionists is directly quoted using Chen's (2005) neutral reporting verb قال 'said' and the same occurs with Ghonim's words about his refusal of such declaration. In contrast, Bargash's words are indirectly quoted. Thus, the quoted voice cannot be distinguished from the authorial voice due to the latter's reproduction or transformation of the actual used words to fit more easily with it. This demonstrates that both voices share the same negative view of Morsi's declaration. His words represent an explicit negative judgment of the presidential declaration as being an expression of dictatorship, repeated twice in different phrasing and a third time in his rejection for a regime of the sort. His words also comprise a call for Morsi to conduct a dialogue to reach a national consensus. Bargash is reported using Chen's (2007) three positive authoritative, accusative, and exhortative reporting verbs: أكدا/فضا 'asserted', رلـا 'rejecting', and 'calling for', respectively. These verbs show the speaker as being powerful, influential, wise, well-intentioned, and concerned to do 
what was right. They also reflect the betrayal by the reported on social actor, namely, Morsi to his pledged democracy via his declaration, being the first democratically elected leader of the state. Such framing of Bargrah's utterance downplays the importance of the MB's speaker about the positive impact of the declaration and casts doubt on the idea that this declaration might have good intentions behind it, as stated in Ghonim's words also refusing it. In fact, the initiative of calling for a national dialogue is assigned to Morsi and the MB in the international newspaper at issue where the opposition is represented as rebuffing such a call until the declaration is rescinded and the constituent assembly is shelved in contrast to the case in the national newspaper. This sheds a positive light on the opposition's flexibility to discuss the matter and reach a compromise. The same negative impression generated in the wrap-up about Morsi's declaration is also created in the headline of the examined report where similarly the unfavorable and favorable views of both anti- and pro-Morsi protesters are, respectively, stated but with more emphasis on the former. This untoward image of the declaration is further stressed in the lead paragraph where the opposition forces are quoted first in the report adversely depicting Morsi because of his declaration as an Islamist dictator who aborted the revolution. In the second half of the report starting in the seventh satellite paragraph, the MB is quoted defending Morsi's decree as a step towards achieving the nation's stability. However, such a view is backgrounded by appearing late in the report and generically expressed, which reveals the newspaper's predilection towards the regime's opposition.

\subsection{Interpretation Stage}

The interpretation phase helps uncover how the reporters relied on internal intertextuality as a discursive tool to legitimize or delegitimize the January 25 and June 30 protests. Investigating the selection of voices, the contextualization of such voices in relation to each other, and the implementation of these voices in the wrapups helps reveal the examined newspapers' perspectives on both the 
January 25 and June 30 protests as reflected in their use and framing of various internal intertextual patterns. Such incorporation and texturing of sources exhibit the dichotomy of positive representation of the ingroup and negative representation of the outgroup in the newspapers' coverage of both Egyptian protests. This Us/Them polarization is evident in both examined newspapers' creation of an antagonist-protagonist structure of voices via giving voice to the ingroup as well as strengthening their words and silencing or challengingthe words of the outgroup, as seen in Section 5.1. In the present section, an overall interpretation of the significant inclusion and exclusion of voices and of the framing of such voices in each newspaper's coverage of both protests is provided. Such interpretation is also supported by a simple counting of the various voiced sources on the part of the conflicting sides, the quotation patterns of their speech, and the reporting verbs used in citing these sources in Tables 1, 2, 3, and 4. This further adds to the revelation of the similarities and differences among the examined newspapers in their use of sourcing to express their stance towards both protests in Section 5.1.

Throughout The New York Times' coverage of the January 25 protests, it gives voice to different parties, but not all voices are given equal prominence. To expound, it uses sources on the anti-regime protesters' part as the primary definers of the situation who are much more often heard than the governmental voice whose words are presented against those of the protesters; that is, the regime's sources are the counter-definers of the situation. Accordingly, it is possible to say that the protesters are demonstrated as powerful and reliable sources of the news since the frequency of quoting from a source, as put by Teo (2000), has a direct relationship with the power and the rank that this source is situated in comparison with the other sources though this is not the usual case with the people who have no accessibility to power sources. To expound, the anti-regime protesters are quoted 98 times in the examined new reports, whereas the regime and its backers are voiced 37 times (see Table 1.p. 30). This shows that 
the last party represents the "Other" for the American newspaper, as patent in Fowler's (1991) words about the "imbalance of access" regarding the limited quoting of the other which "results in partiality, not only in what assertions and attitudes are reported - a matter of content - but also how they are reported" (pp. $22-$ 23). Moreover, the newspaper's coverage is not balanced with relation to the regime's reported opponents in the sense that the public protesters whether ordinary citizens at different ages or independent youth activists are highly more quoted than political opposition forces and leading figures (91 to 7). This helps legitimize the anti-regime protests due to being popular, spontaneous, and devoid of political agendas and interests. In contrast, the official voice represented by only two sources Mubarak and Suleiman through their televised statements and speeches prevails over the regime's public protesters (30 to 7) quoted mainly via their chants only on Feb. 2, namely, the Battle of the Camel, which reflects the unpopularity of the regime's counter protests. This conforms to the negative depiction of their rallies and attacks on the protesters in Tahrir Square as being orchestrated in collusion with the regime to suppress the protests in the analyzed news reportsdated Feb2. In the American newspaper's, both the protesters and regime via its Interior Ministry are voiced from the very onset of the protests on Jan. 25 . However, the most repeated voices on the regime's part are Mubarak quoted six times starting on Jan. 28 and Suleiman seven times starting on Feb. 8, and both are negatively contextualized. The most common source on the protesters' part is ElBaradei cited five times starting on Jan. 28 adversely depicting the regime's violence against the protesters as acts of thugs, as seen in the examined report (b) dated Jan. 28.

It can also be observed in the American newspaper that the defined sources by name, age, occupation, titles, credentials, institution capacities and/or political belongings are much more than the anonymous sources quoted on the part of the conflicting sides ( 88 to 47) (see Table 1, p. 30). Such identification renders their 
statements and arguments convincing and trustworthy, as held by Zaher (2009), since the exact figures even among ordinary people make the reports more factual (Stenvall, 2008). However, the importance of this identification emerges upon pointing out that those named on the protesters' side belong to the public much more than the opposition forces (45 to 16). This asserts the popularity of the anti-regime protests and the diversity of sources and hence shows the newspaper as representing a common vision of the Egyptian nation against the regime. Besides, it highlights the newspaper's intended plan to directly access the public protesters as opposed to the regime's public supporters, from whom only one named person is voiced, while the rest of the defined on the regime's part are Mubarak, Suleiman, and the Interior Ministry. This emphasizes the unpopularity and the non-diversity of the president's counter protests. Accordingly, it can be noted that more effort was exerted by the newspaper to reach the anti-regime public protesters, which puts them in a more powerful position than their counterparts whose dehumanization helps marginalize them much more, as stated by Eissa (2015) and Juan (2009).

As far as the quotation types are concerned, the most common pattern in The New York Times is the direct quotation (66/135) used mainly to cite the anti-regime protesters $(55 / 98)$, i.e. the primary definers, which, in turn, renders their words factual, credible, and newsworthy, as stated by Cotter (2010), Richardson (2007) and van Ginneken (2002) (see Table 1, p. 30). In contrast, the indirect quotation is more utilized with the regime's sources (18/37), i.e. the secondary definers, which reflects less accuracy and more distortion of their original speech at the reporter's hands and hence greater interpretation that fits with his attitude towards them. In other words, the number and use of the direct and indirect quotations with a particular social actor(s) along with their positioning can help find out the power relations and highlight the bilateral relation of power and language in a text. The strategic quotation is used with all the conflicting sides very limitedly (11/135) but a bit more with the regime than the protesters ( 8 to 3 ). It is basically used with the 
former to indicate the reporter's distancing himself from the truth claim of the speaker in order to underpin the bias implied by such quoted term or expression. In addition, it can be underpinned that the neutral reporting verbs are the most frequent in citing the regime and its opponents (95/123) though the American newspaper's stance towards both is not neutral, as described in Section 5.1.1. ${ }^{(1)}$

Table 1: The New York Times' Representation of Sources in January 25 Protests

\begin{tabular}{|c|c|c|c|c|c|c|c|c|c|c|c|c|}
\hline \multirow{2}{*}{\multicolumn{2}{|c|}{ Conflicting Sides }} & \multirow{2}{*}{\multicolumn{2}{|c|}{$\begin{array}{l}\text { Overall } \\
\text { No. of } \\
\text { Sources }\end{array}$}} & \multirow{2}{*}{ Defined } & \multirow[b]{2}{*}{ Anonymous } & \multicolumn{4}{|c|}{ Quotation Types } & \multicolumn{3}{|c|}{ Reporting Verbs } \\
\hline & & & & & & Direct & Indirect & Strategic & $\begin{array}{c}\text { Transformed } \\
\text { Indirect }\end{array}$ & Neutral & Positive & Negative \\
\hline \multicolumn{2}{|c|}{ Protesters } & \multicolumn{2}{|c|}{98} & 61 & \multirow{2}{*}{37} & \multirow{2}{*}{55} & \multirow{2}{*}{40} & \multirow{2}{*}{3} & \multirow{2}{*}{ - } & \multirow{2}{*}{74} & \multirow{2}{*}{11} & \multirow{2}{*}{7} \\
\hline Public & Opposition & 91 & 7 & \begin{tabular}{|l|l|}
45 & 16
\end{tabular} & & & & & & & & \\
\hline \multicolumn{2}{|c|}{ Regime } & \multicolumn{2}{|c|}{37} & 27 & \multirow{2}{*}{10} & \multirow{2}{*}{11} & \multirow{2}{*}{18} & \multirow{2}{*}{8} & \multirow{2}{*}{-} & \multirow{2}{*}{21} & \multirow{2}{*}{9} & \multirow{2}{*}{1} \\
\hline Officials & Supporters & 30 & 7 & 261 & & & & & & & & \\
\hline \multicolumn{2}{|c|}{ Total } & \multicolumn{2}{|c|}{135} & 88 & 47 & 66 & 58 & 11 & - & 95 & 20 & 8 \\
\hline
\end{tabular}

In contrast to the international newspaper's constant positive representation of the protesters as the primary definers of the situation, the Egyptian privately-ownedAl-Masry Al-Youm tends to include and exclude voices representing different sides of the conflict depending on the power balance during the days of the protests. Although the anti-regime protesters are quoted slightly more than the regime and its supporters (54 to 43 ), they cannot be considered the primary definers throughout the 18-day protests, for, as Fairclough (1995b) maintained, equity and balance cannot be assessed by merely noting which voices are represented and how much space is given to each (see Table 2, p.33). The difference and

(1) It is important to note that the number of the reporting verbs in the analyzed data is less than the number of the used quotations because of three reasons (see Tables 1-4, pp. 30-37). First, two different quotation types of some cited source are reported using one verbal process. Second, some strategic quotations are reported without using a verbal process. Third, transformed indirect quotations are reported using either mental state verbs or transitive verbs, not verbal processes, and such verbs do not belong to Chen's $(2005,2007)$ three types of reporting verbs. Hence, they are not included in the counting of the employed verbal processes in the examined news reports. 
hence the significance appear in the number and framing of the quoted sources on each conflicting side in the two stages of the newspaper's representation of voices. To elucidate, the newspaper's coverage of the protests up to and including the Battle of the Camel on Feb. 2 is characterized by an emphasis on the voice of the regime's supporters, not even the governmental voice (33 to 6), which reveals the representativeness of the counter protests. In contrast, the anti-regime protesters are quoted 23 times; the public protesters angry at the state police and the NDP are quoted more than the opposition forces (18 to 5). In addition, the public protesters' quoted utterances mainly represent their chants, not the full detailed statements unlike the regime's backers who are quoted via both their chants and statements; hence, the latter can be considered the primary definers. To explain, the voice of Mubarak's counter protests venerating his role as the 30 -year president of the stable country and believing in his promises of future political and economic reforms is dominant in the newspaper's coverage after Mubarak's second televised speech to the nation on Feb. 1. This augments Mubarak's positive image and worsens the image of the obstinate young protesters who were insisting on his departure. The most repeated voice in stage one of the newspaper's presentation of voices, namely, pre-Friday of Departure on Feb. 4 representing the largest million protest against the regime in response to the Battle of the Camelis Mubarak quoted three times starting on Jan. 28 and presented positively, as seen in the examined report (a) dated Jan. 29 via his first speech in which he ordered the nationwide curfew to save the country. However, both the regime and its opponents are quoted from the very first day of the protests on Jan. 25 through the Interior Ministry and groups of protesters, respectively, and presented negatively, as noted in the examined report dated Jan. 26.

Furthermore, it can be plainly observed that, unlike the international newspaper, Al-Masry Al-Youm employs much more anonymous voices than defined voices throughout its coverage of the protests ( 75 to 22) (see Table 2, p. 33). This, in turn, helps the newspaper's ideological stance be integrated in the speech of 
such unknown voices and thus be more easily passed to the readers. To illustrate, in the pre-Friday of Departure stage, all the quoted sources on the protesters' side are anonymous, which displays them as less trustworthy and their words as less valuable, and even the political opposition groups who were supposed to be known by many Egyptians are not given names. Another explanation is that some of these sources in the Egyptian context might request to be kept anonymous so as not to be identified and tracked down by the authorities since the protests at this stage did not gain enough momentum and the regime was still in control of the state. This deprives the readers of the ability to identify with them and their demands and could explain why the opposition forces are very less cited than the public protesters. The pro-regime protesters are also mostly undefined groups except for six individualized voices defined by full name, job, and/or their dwelling district, which makes them seem factual, as argued by Stenvall (2008) and Juan (2009). However, the anonymity of the former makes it difficult to challenge their statements since the dehumanized anonymous speakers act as an "imaginary interlocutor" (Fairclough, 2003, p. 48). This, hence, could help the reporter convey his view via the words of the unknown speakers. As for the official voice, it is mostly defined (4 times) and represented positively by Mubarak via his televised speeches on Jan. 28 and Feb. 1 and negatively by the Interior Ministry as the initiator of violence against the protester, as noted in the analyzed reports dated Jan. 29 and Feb. 3.

Moreover, in stage one in Al-Masry Al-Youm, the indirect quotation, different from the international newspaper, is the most frequent with the conflicting sides $(28 / 62)$ but close to the direct quotation in the number of occurrences on the protesters' and regime's sides (24) (see Table 2, p. 33). However, it is important to highlight that direct quotation on the protesters' part represent mainly chanted slogans against the regime, not their views or descriptions of incidents, while such quotation pattern is used mainly in reporting the statements of the regime and its 
advocates, which increases the value of their words and yields them more persuasive. As to strategic quotation, it is very restrictedly used on both conflicting sides (8 times) to only demonstrate that reporting is not prejudicial. In addition, though the newspaper's account of the quoted voices is not neutral, the neutral reporting verbs are the most utilized with both conflicting sides (39/58) followed by the positive verbal processes (18).

The protests started to gain momentum after the Friday of Departure on Feb. 4, i.e. stage two of the newspaper's representation of voices. Accordingly, the official voice wanes in Al-Masry Al-Youm's coverage of stage two to the extent that it is quoted only four times and disappears totally in the examined report on Feb. 8 mega protest calling for Mubarak's departure though he is not presented negatively in the authorial voice until his last address on Feb. 10. In contrast, the protesters' voice becomes dominant to the degree that they are quoted 31 times, and their words comprise chants and detailed statements speaking negatively of the regime (see Table 2, p.33). Thus, they are considered to be more of main definers of the situation during the last 8 days of the protests unlike the official voice which is considered to be the secondary definers during this period of time. Nevertheless, the cited opposition figures are still much less than the public protesters (5 to 26), which, in turn, underscores the newspaper's need for stressing the increasing popularity of the protests and thus heightening the legitimacy of their demands, particularly Mubarak's departure.

Similar to stage one, the quoted anonymous voices are more than the named voices (23 to 12) in Al-Masry Al-Youm's coverage of stage two; however, there are eight personalized voices on the protesters' part, three of which belong to the public and five of which belong to the political opposition(see Table 2, p. 33). This augments the validity of their speech, makes it easy for the readers to identify with them, and shows that their fear of being tracked down diminished, for the regime started to lose control and the protests gained more force. The rest of their 
voices are anonymous groups of protesters (23) chanting the demand of Mubarak's removal and condemnation of the regime in addition to full utterances describing and stating their negative opinions of the regime and the then situation. As for the regime's sources, they are presented by Mubarak and Suleiman through their public statements. In this stage, Mubarak is quoted twice via his Feb. 10 final address, and no voice is particularly repeated on the protesters' part even among the opposition figures, as opposed to the international newspaper at issue where ElBaradei and the $\mathrm{MB}$, for example, are repeatedly voiced, the first of whom is totally silenced in Al-Masry Al-Youm. Perhaps, this is because it attempts to appear impartial towards all political opposition forces since it is a privately-owned newspaper known for its non-affiliation with a particular party (see Section 4).

Like stage one, the indirect quotation, in stage two, is much more used than the other patterns $(21 / 35)$ (see Table 2, p. 33). Nonetheless, it is more utilized with the protesters (19/31), while both indirect and direct quotations are equally used with the regime (2 to 2). It can be concluded that Al-Masry Al-Youm, through using the indirect quotation, opts for minimizing the difference between the voice of the reporter and the voice of the reported sources for ideological purposes. Different from stage one, the most common reporting verbs belong to Chen's (2007) positive category of verbal processes (21/34) followed by the neutral verbal processes (13), and this applies to both the protesters and the regime. This could go back to the fact that the protesters are represented overtly in a favorable light in this stage as being peaceful, legitimate, and more powerful than the regime, while the regime is cited only through its official declarative statements, namely, Mubarak's last speech and Suleiman's announcement of the president's resignation. 
Table 2: Al-Masry Al-Youm's Representation of Sources in January 25

Protests



In contrast to the international newspaper's negative depiction of Mubarak's regime and positive depiction of the January 25 protesters, it can be observed, in the analyzed data on the June 30 protests, that the newspaper creates the dichotomy of the Us and Them in their portrayal of Morsi and his allies versus the anti-Morsi protesters, respectively, through their representation of voices. To elucidate, different from The New York Times' depiction of sources in its coverage of the January 25 protests, it employs the regime's sources as the primary definers of the situation in its coverage of the June 30 protests, while the anti-Morsi protesters are employed as the secondary definers and their words are presented against those of the regime. The official voice and its backers prevail over its opponents (73 to 49) (see Table 3, p. 35). Moreover, the official voice of the regime surpasses that of its public supporters (60 to 13). However, 
dissimilar to the case in the newspaper's coverage of the January 25 protests where only Mubarak and Suleiman represent the official voice, a variety of governmental voices including the president, the $\mathrm{MB}$, and the dominant political FJP are incorporated defending Morsi's constitutional declaration, approval of the draft constitution, and call for national dialogue to resolve the internal political conflict. Furthermore, the number of the quoted voices of both the anti-regime public protesters and known opposition figures and forces is close (27 to 22) unlike the quoting of the former much more than the latter in the coverage of the January 25 protests. This is because the newspaper mainly portrays the political crisis as being a mere conflict of power between two political forces: the liberals and seculars, on the one hand, and the Islamists led by the MB, on the other. That is, it was the political interests that were governing the situation, not the public's demands or dissatisfaction with the regime. Both the voices of the opposition and the regime appear in the coverage of the first anti-regime protests on Nov. 22 until Morsi's ouster on July 3 , but the voices that are tremendously maintained throughout are those of the regime and its proponents. The most repeated voices on the regime's part in the data analyzed are Morsi, cited 21 times starting on Nov. 22 and the MB 11 times starting on Nov. 23 and on the protesters' part is ElBaradei quoted six times only on Nov. 29 and Dec. 5.

Like The New York Times' identification of the cited sources in its coverage of the January 25 anti-regime protests, the defined sources are much more quoted than the anonymous sources (79 to 43) (see Table 3, p. 35), which, as put by Juan (2009) and Stenvall (2008), renders the former's utterances factual whether positive or negative of a particular side. However, the importance of such identification whether by name, age, occupation, titles, credentials, political belongings, and/or institutional capacities emerges upon highlighting that the voices of the regime and the MB are the defined, not the public supporters (54 to 1). This reflects that the former are the dominant voices and more sought to be heard by 
the newspaper, and hence more trustworthy in contrast to the public voice whether on the supporters' side or the protesters' side. The latter's defined and anonymous voices are almost equal (24 to 25 ), and the named sources mostly belong to the political opposition (19). This shows the conflict between both camps as essentially political and lessens the effect and value of the unnamed public protesters' speech against the regime contrary to the mainly defined quoted January 25 public protesters.

Contrary to The New York Times' common direct quotation in its examined reports on the January 25 protests, the indirect quotation is the most frequent with the conflicting sides (61/122) followed by direct quotation (42) (see Table 3, p. 35). The importance of the frequency of such a pattern lies in the fact that it is more apparently used with the protesters, i.e. the counter definers $(30 / 49)$ than the regime $(31 / 73)$. This lends the reporter more powers to play with the quoted protesters' actual words so as to serve the regime's interests, i.e. the ingroup. Moreover, the strategic quotation is much more commonly used in reporting the regime than its opponents (17/18), as in the coverage of the January 25 protests. However, it is mainly employed to underpin either the contentious articles of both Morsi's declaration and draft charter or the regime's negative description of its rivals as connivers as well as its initiative to reach a consensus. This is an attempt on the newspaper's part to only demonstrate that reporting is not prejudicial since the newspaper's support for the regime's stand is manifested in the immediate context surrounding any strategic quotation. Furthermore, similar to the newspaper's coverage of the January 25 protests, Chen's (2005, 2007) neutral reporting verbs are the most prevalent in citing the conflicting sides $(65 / 112)$ followed by the positive verbal processes (39), but this does not signify the newspaper's neutral stance towards the investigated protests, as patent in the analysis of the examples in Section 5.1.2. 
Table 3: The New York Times' Representation of Sources in June 30

Protests

\begin{tabular}{|c|c|c|c|c|c|c|c|c|c|c|c|}
\hline \multirow{2}{*}{\multicolumn{2}{|c|}{ Conflicting Sides }} & \multirow{2}{*}{$\begin{array}{c}\text { Overall } \\
\text { No. of } \\
\text { Sources }\end{array}$} & \multirow[b]{2}{*}{ Defined } & \multirow[b]{2}{*}{ Anonymous } & \multicolumn{4}{|c|}{ Quotation Types } & \multicolumn{3}{|c|}{ Reporting Verbs } \\
\hline & & & & & Direct & Indirect & Strategic & $\begin{array}{c}\text { Transformed } \\
\text { Indirect }\end{array}$ & Neutral & Positive & Negative \\
\hline \multicolumn{2}{|c|}{ Protesters } & 49 & 24 & & & & & & & & \\
\hline Public & Opposition & \begin{tabular}{|l|l|}
27 & 22 \\
\end{tabular} & \begin{tabular}{l|l}
5 & 19
\end{tabular} & 25 & 17 & 30 & 1 & 1 & 29 & 12 & 5 \\
\hline \multicolumn{2}{|c|}{ Regime } & 73 & 55 & \multirow{2}{*}{18} & \multirow{2}{*}{25} & \multirow{2}{*}{31} & \multirow{2}{*}{17} & \multirow{2}{*}{ - } & \multirow{2}{*}{36} & \multirow{2}{*}{27} & \multirow{2}{*}{3} \\
\hline Officials & Supporters & \begin{tabular}{|l|l|}
60 & 13 \\
\end{tabular} & \begin{tabular}{l|l}
54 & 1 \\
\end{tabular} & & & & & & & & \\
\hline & otal & 122 & 79 & 43 & 42 & 61 & 18 & 1 & 65 & 39 & 8 \\
\hline
\end{tabular}

Contrary to the examined international newspaper, $\mathrm{Al}$ Masry Al-Youm gives more space to the anti-regime protesters to express themselves than the regime and its advocates (69 to 24) (see Table 4, p. 37). Similar to theinternational newspaper, the Egyptian newspaper voices the public protesters slightly more than the opposition forces (39 to 30). However, the difference lies in the fact that both are favorably positioned and repeatedly referred to together as the civil, national, and revolutionary forces or the Egyptian revolution masses as opposed to the MB's regime and its Islamists supporters. This, in sequence, reveals the representativeness of the anti-regime protests in face of the Islamist regime. That is, the former represent the main definers and the latter represent the counter definers. Moreover, the newspaper focuses on the official voice represented by Morsi, the $\mathrm{MB}$, and the FJP, i.e. basically MB members at the expense of its public supporters whose quoted words are merely chants (22 to $2)$. Because the official sources are either backgrounded or negatively contextualized, the incorporation of such sources and the near absence of the voice of the regime's public supporters draw an image of the nation's internal crisis as being the Islamist ruling camp defying the Egyptians in contrast to voicing much more regime's proponents in the newspaper's coverage of the January 25 protests. This image is ascertained through quoting the $\mathrm{MB}$ and its leaders being the dominant political force then from the very beginning of the internal conflict instead of Morsi and his government, as if the former were the true leaders of the country, which represents the view of the regime's opponents at that time. Both the regime, represented by the $\mathrm{MB}$, and the 
protesters are quoted from the very first protests against Morsi on Nov. 22. The most repeated voices on the regime's part are the MB cited 13 times starting on Nov. 22 as well as Morsi four times starting on July 1, and the regime's voice is totally absent from the newspaper's analyzed report on June 30, namely, the eruption of the largest million protests calling for Morsi's downfall. The most frequent voices belonging to the protesters are two of the NSF leaders: AmrMousa cited seven times and ElBaradei three times on Nov. 22 and July 3, and Tamarrod movement two times starting on July 1.

Besides, like the American newspaper, Al-Masry Al-Youm cites far more defined than anonymous sources on the part of the conflicting sides (66 to 27) different from its coverage of the anti-Mubarak protests (see Table 4, p. 37). This could go back to the fact that such named sources were not afraid of being pursued by the authorities unlike the case during Mubarak's rule since the anti-Morsi protests gained momentum from their very beginning and Morsi was not in full control of the state apparatuses. However, no public protesters are defined but only opposition figures and revolutionary forces supported by the Egyptian masses, which renders their demands reliable and important and helps the readers identify with them. Moreover, no Islamist force other than the $\mathrm{MB}$ and no defined public protester are given space to express themselves except for EL-Nour party cited only once on Nov. 22 in support of Morsi's declaration. This, in turn, devaluates the significance of the quoted statements on the part of the regime's anonymous voices and indicates that the $\mathrm{MB}$, as a political force, was the one and only power that was governing Egypt then and controlling its political life.

Like the American newspaper, the indirect quotation is the most common in the Egyptian newspaper in citing the conflicting parties (52/93) as is the case in the newspaper's coverage of the January 25 protests (see Table 4, p. 37). Nevertheless, such quotation type tremendously prevails over the direct quotation that comes second in the number of occurrences (22) in 
comparison to the American newspaper at hand, which makes the voice of the Egyptian newspaper more apparent. Moreover, the strategic quotation is scarcely used like the American newspaper but almost equally employed on the part of the protesters (9) and the regime (8). Such type of quotation is used when citing the former negatively describing Morsi, his declaration, and the draft constitution in an attempt by the newspaper to be only cautious regarding the bias in the quoted expressions, as noted in the examined report dated Nov. 23. In contrast, it is used to cite the regime when negatively describing the protesters and the army's role in the internal crisis and positively depicting Morsi's decrees in a bid by the newspaper to reflect its disapproval of the truth claim of the quoted expressions, as evident in the context of the quoted utterances. Unlike the American newspaper where the neutral reporting verbs prevail over the positive verbs, the former are used slightly more than the latter in citing the involved social actors in the Egyptian newspaper (44 to 37). This might go back to the fact that the negative representation of the regime through its voiced opponents who are almost equally assigned positive and neutral verbal processes (29 to 31 ) is enormously dominant in the Egyptian newspaper as manifested in the number of times the latter is quoted which exceeds the former's by 46 times. In contrast, in the American newspaper, the adverse representation of the anti-regime protesters via the regime's voiced sources is a bit more common than the protesters' negative portrayal of the regime where the former surpass the latter by 22 times. This reveals that the Egyptian newspaper's support for the ingroup appears clearly in its focus on quoting a bigger number of sources on their part than the outgroup. 
Table 4: Al-Masry Al-Youm's Representation of Sources in June 30 Protests

\begin{tabular}{|c|c|c|c|c|c|c|c|c|c|c|c|}
\hline \multirow{2}{*}{\multicolumn{2}{|c|}{ Conflicting Sides }} & \multirow{2}{*}{$\begin{array}{c}\text { Overall } \\
\text { No. of } \\
\text { Sources }\end{array}$} & \multirow[b]{2}{*}{ Defined } & \multirow[b]{2}{*}{ Anonymous } & \multicolumn{4}{|c|}{ Quotation Types } & \multicolumn{3}{|c|}{ Reporting Verbs } \\
\hline & & & & & Direct & Indirect & Strategic & $\begin{array}{l}\text { Transformed } \\
\text { Indirect }\end{array}$ & Neutral & Positive & Negative \\
\hline \multicolumn{2}{|c|}{ Protesters } & 69 & 44 & \multirow{2}{*}{25} & \multirow{2}{*}{18} & \multirow{2}{*}{40} & \multirow{2}{*}{9} & \multirow{2}{*}{2} & \multirow{2}{*}{31} & \multirow{2}{*}{29} & \multirow[b]{2}{*}{ - } \\
\hline Public & Opposition & \begin{tabular}{|l|l|}
39 & 30 \\
\end{tabular} & \begin{tabular}{l|l}
- & 44 \\
\end{tabular} & & & & & & & & \\
\hline \multicolumn{2}{|c|}{ Regime } & 24 & 22 & \multirow{2}{*}{2} & \multirow{2}{*}{4} & \multirow{2}{*}{12} & \multirow{2}{*}{8} & \multirow{2}{*}{-} & \multirow{2}{*}{13} & \multirow{2}{*}{8} & \multirow{2}{*}{ - } \\
\hline \begin{tabular}{|l} 
Officials \\
\end{tabular} & Supporters & \begin{tabular}{l|l}
22 & 2 \\
\end{tabular} & \begin{tabular}{l|l}
22 & - \\
\end{tabular} & & & & & & & & \\
\hline \multicolumn{2}{|c|}{ Total } & 93 & 66 & 27 & 22 & 52 & 17 & 2 & 44 & 37 & - \\
\hline
\end{tabular}

Such interpretation of the incorporation and positioning of the various quoted voices revealed the dichotomous model of Us vs. Them in each newspaper's coverage of both protests, as elucidated in Tables 5 and 6:

Table 5: The Dichotomous Model of Us vs. Them in the January 25 Protests Coverage

\begin{tabular}{|c|c|c|c|}
\hline \multicolumn{2}{|c|}{ The New York Times } & \multicolumn{2}{|c|}{ Al-Masry Al-Youm } \\
\hline \multirow[t]{2}{*}{ Ingroup } & \multirow[t]{2}{*}{ Outgroup } & Ingroup & Outgroup \\
\hline & & \multicolumn{2}{|c|}{ Pre-Friday of DepartureCoverage Phase } \\
\hline \multirow[t]{4}{*}{$\begin{array}{l}\text { anti-Mubarak } \\
\text { protesters }\end{array}$} & \multirow[t]{4}{*}{$\begin{array}{l}\text { Mubarak's } \\
\text { regime } \\
\text { supporters }\end{array}$} & $\begin{array}{l}\text { Mubarak } \\
\text { supporters }\end{array}$ & $\begin{array}{l}\text { anti-Mubarak protesters } \\
\text { hidden hands } \\
\text { police }\end{array}$ \\
\hline & & \multicolumn{2}{|c|}{ Post-Friday of DepartureCoverage Phase } \\
\hline & & $\begin{array}{l}\text { anti-regime } \\
\text { protesters }\end{array}$ & $\begin{array}{c}\text { Mubarak's regime in the } \\
\text { quoted voices }\end{array}$ \\
\hline & & & $\begin{array}{l}\text { Mubarak after his final } \\
\text { address in its authorial } \\
\text { voice }\end{array}$ \\
\hline
\end{tabular}

Table 6: The Dichotomous Model of Us vs. Them in the June 30 Protests Coverage

\begin{tabular}{||c|c|c|c||}
\hline \multicolumn{2}{|c|}{ The New York Times } & \multicolumn{2}{c|}{ Al-Masry Al-Youm } \\
\hline Ingroup & Outgroup & Ingroup & Outgroup \\
\hline Morsi & anti-Morsi protesters & anti-Morsi & Morsi \\
MB & & protesters & MB \\
public Islamist backers & & & all Islamists \\
& & & supporters \\
\hline
\end{tabular}

The interpretation phase can be understood in much depth through an explanation of the social practices of the newspapers, 
i.e. the relation of news discourse to other social institutions and wider social factors, which shaped their ideological stances towards both protests.

\subsection{Explanation Stage}

This stage of Fairclough's (1995a) model of CDA helps examine the power relations which shaped the January 25 and June 30 protests discourse. Therefore, it is drawn upon the political affiliation of the two newspapers at issue and the notion of media as an ISA in the sense of Althusser (1971) which explain how the investigated news discourses representation of both protests was bound to the ideological stances of their news institutions in relation to the then official ideological mainstream views. Numerous scholars maintained that media mediates the ruling class' ideology through its content; that is, the media cannot be seen separately from state institutions or other elite powerful groups (Ashley \& Olson, 1998; Blommaert, 2005; Cotter, 2010; Cottle, 2000; Dunlevy, 1998; Fairclough, 1994, 2003, 2006; Fowler, 1991; Gitlin, 1980; Herman \& Chomsky, 2002; Hodge \& Kress, 1993; Iggers, 1999; Manning, 2001;McLeod, 1995; McLeod \&Hertog, 1992; McQuail, 1993; Molotch\& Lester, 1974; Murdock, 2000; Richardson, 2006, 2007; Tuchman, 1978; van Dijk, 1991, 1993a, 1996, 1998, 2000; Wayne, 2003). Thus, the media discourse can be manipulated to sustain or resist hegemony at times of crisis, for example, based on the then power balance.

To expatiate, the examined newspapers' coverage of the January 25 and June 30 protests is ideologically biased and slanted, as reflected in their use of internal intertexuality. It can be pointed out, based on the description and interpretation levels of analysis (see Sections $5.1 \& 5.2$ ), that The New York Times' coverage of the January 25 protests evinces that it was prone to take the side of the protesters by depicting them positively, 
through the quoted voices, as people fighting for the democracy other Westerns cherished and picturing Mubarak as a dictator killing his people to stay in power. This could be reflective of the fact that the American newspaper is liberal-bound (Brennan, 2012; Okrent, 2004); that is, it is supposed to defend democracy and civil as well as political rights. Furthermore, President Obama entirely supported the pro-democracy protests and announced his disapproval of any violence committed against them, but his stand towards Mubarak was not definite at the outbreak of the protests, as maintained by Green (2011) and Ross, Moore, and Swinford, (2011). In fact, Ross et al. highlighted that the White House was backing Egyptian pro-democracy activists while dealing with Mubarak in public as their closest ally in the Middle East. Despite the fact that Obama, at first, urged Mubarak to work seriously on political reforms, he eventually called for an urgent transitional government headed by Vice President Omar Suleiman after the Battle of the Camel on Feb. 2 (Holmes, 2012; Sharp, 2013). Such battle resulted in a crack between the US administration and Mubarak's regime since the former overtly asked him to stop violence against the peaceful protesters (Holmes, 2012; Sharp, 2013). That is, when Egypt's stability was endangered by the public protests against Mubarak, the US supported the army's takeover. In fact, The New York Times is an example of the mainstream media influenced by powerful institutions like governments (Ashley \& Olson, 1998; Blommaert, 2005), one of the elite media outlets affecting both decision makers and the public (Chomsky, 1997; Herman \& Chomsky, 2002), and known for its support for Democrat Obama (Ansolabehere et al., 2004; Brennan, 2012). That is, it belongs to an ISA that somehow endorses the given government's evaluation, interpretation, and perspective of particular events (Althusser, 1971). These could be considered grounds for its favorable representation of the antiMubarak protests. 
As far as the June 30 protests are concerned, the international newspaper was inclined to side against the anti-Morsi protesters in favor of the Islamist president to the extent that it called the Egyptian military's intervention to satisfy the people's will a coup, as stated in its examined reports dated July 1 and 3. This goes against the newspaper's liberal perspective concerning supporting people's civil rights. That is, the news outlet should have supported the anti-Morsi protesters considering Morsi a new autocrat, similar to Mubarak, who did not really work on promoting democracy and providing fundamental reforms of any kind. The stance of the American newspaper, being a mainstream media outlet as explained above, might be more or less indicative of the American official mainstream views. To illustrate, Ibrahim (2013) stated that the Obama administration, via the U.S. Ambassador to Egypt Anne Patterson, announced its support for the Egyptian government and refusal of turning Egypt into a military state. Moreover, Obama repeatedly asked the opposition in general and the Copts in particular not to protest against Morsi being a democratically elected president dissimilar to Mubarak but to have dialogue with Morsi, instead. In addition, the White House only urged Morsi, as stated by Hauslohner (2013), to respond to the protesters' demands regarding democracy but not departure which represented their main demand and asked both Morsi's opponents and allies to stop violence and engage in dialogue. This exhibits the US' endorsement of Morsi and the MB. Though Obama avoided using the word coup to explicitly describe the military intervention, he threatened, as Alexander (2013) and Martin (2013) pinpointed, that such intervention could influence the US' annual financial aid to Egypt and demanded the military to stop arbitrary detentions of Morsi and his backers. In fact, the US' official mainstream ideological view could interpret the investigated international newspaper's bias against the June 30 protests. 
Unlike the American newspaper, there were signs of neutrality in Al-Masry Al-Youm in the very first days of the January 25 protests stemming from the coverage of the privatelyowned newspaper. It is known for being an opposition newspaper despite its non-adoption of the views of particular parties, aiming at providing a balanced coverage and securing a space of criticism of the government unlike the state-owned newspapers (Arab West Report, 2008; Cooper, 2008; Elmasry, 2012; Pasha, 2011). Such signs were embodied in its sympathy for the killed protesters at the hands of the vicious police forces. At the same time, the newspaper's coverage contained undeniable signs of visualizing the destructive effects of the protests and their threats to the nation's national security that started to explicitly appear on Jan. 28 in addition to the conspirational political forces intriguing against the nation appearing after the president's Feb. 1 address to the nation. Al-Masry Al-Youm, after the Battle of the Camel and the resultant Friday of Departure mega protest persistently calling for Mubarak's departure, changed its tone to be positive towards the protesters and excessively quoted them but was still inclined towards Mubarak by avoiding depicting him negatively in its authorial voice. Such an indecisive attitude of the private newspaper and its decision to remain in the comfort zone might reflect the uncertainty of that period as there was still no indication of whether Mubarak's regime would continue or be overthrown, and hence the journalists could be tracked down if Mubarak succeeded to remain in power. It possibly reveals the newspaper's fear to be confiscated by the state Supreme Council of Journalism which, as stated by Pasha (2011), Rubin (2015), and Rugh (2004), forced censorship on all types of national newspapers. That is, as the protesters gained momentum and the government's position became relatively weaker, the national newspaper adopted different reporting strategies. This also appeared in Al-Masry Al-Youmwhen it started to adversely paint 
the president in its authorial voice, not only the quoted voices, after his final defiant address on Feb. 10 which incited national and international severe criticism.

In contrast, Al-Masry Al-Youm totally sided with the antiMorsi protests from the very beginning to the extent that it disregarded Morsi, his MB, and Islamist allies in many of its reports on the June 30-July 3 protests, which is also against the newspaper's claim for objective reporting. However, its attitude somewhat accords with the view that its coverage is sometimes reliant on criticizing the government and regime, being a privately-owned newspaper (Arab West Report, 2008; Cooper, 2008). In fact, Elmasry and el-Nawawy (2014) highlighted that Al-Masry Al-Youm'snews coverage was significantly more critical of Morsi in 2013 than of Mubarak during his rule. This could be explained, as maintained by El Issawi (2014) and Harper (2014), in association with the liberal vs. the Islamist media narratives, with the former being against the regime and the latter assuming the role of the state media during Mubarak's rule and thus defending the regime and its vision. Morsi, unlike Mubarak's thirty years in power during which he along with his NDP maintained control over local media (Rugh, 2004), did not rule for enough time to be able together with the MB to get the same full control over state-owned and independent media outlets representing the liberal opposition then (El Issawi, 2014; Elmasry\& el-Nawawy, 2014; Harper, 2014). Instead, they published their own Islamist media, along with their supportive political Islamist forces. In other words, the media narratives then began to polarize around the two sides of the political conflict in Egypt: the Islamists and the liberal opposition (El Issawi, 2014). That is why, a severe attack was launched against the anti-Morsi and anti-MB journalists and media figures although Egypt's postJanuary 25 protests democratically elected president was supposed to secure freedom of expression, being a revolutionary demand (El Issawi, 2014; Harper, 2014). 


\section{Conclusion}

The two research questions (see Section 2) were addressed by analyzing internal intertextualitythrough Fairclough's (1995a) description stage, by underpinning the relationship between text in this respect and interaction through his interpretation stage via highlighting van Dijk's (1995d, 2000) Us/Them dichotomy, and finally by underscoring the relationship between the ideological references revealed in the second stage and the social context through his explanation stage. Such a three-stage analysis provided the findings below.

The present study displayed that the examined newspapers manipulated internal intertextuality to represent their ideological perspectives on both Egyptian protests. This lends support to the idea that the language used to represent the world is not valuefree or coincidental and there are power relations underlying it, as believed by the CDA scholars (e.g. Blommaert\&Bulcaen, 2000; Fairclough, 1989, 1992, 1993, 1995a; Fairclough\&Wodak, 1997; Hodge \& Kress, 1993; Huckin, 2002; van Dijk, 1980, 1983, 1991, 1993b, 1995a, 1995b, 1996, 1997, 2001; Wodak, 1996).The analysis of such intertextual feature in the present study demonstrated the international newspaper's constant support for the anti-Mubarak protests and bias against the antiMorsi protests as opposed to the national newspaper's two-stage coverage of the anti-Mubarak protests based on its evaluation of the power balance then and its full support for the anti-Morsi protests from its very first moment. This indicates that the American press discourse, in line with Youssef (2012), was more ideologically consistent in reporting on the protesters and the regime during both protests than the Egyptian press discourse.

The analysis of internal intertextuality led to uncovering the examined newspapers' dichotomous Us/Them model in their coverage of both protests through the help of van Dijk's (2000) 
ideological square, which underscores that their coverage was ideologically biased. This highlights the subjectivity of the news reporting discourse; such discourse contains values, attitudes, and ideas, not mere facts (Cotter, 2010; Fairclough, 1994, 2003; Fowler, 1991; Hodge \& Kress, 1993; Richardson, 2007; van Dijk, 1988, 1991, 1993a, 1998). According to the present study, it can be concluded, in correspondence to Fairlcough (2003), that including and excluding voices, selecting what is to be reported, and framing such voices in relation to each other and to the authorial voice in favor of a particular party promote a news outlet's ideological stance towards a particular reported event. This, in turn, generates an antagonist-protagonist structure that results in an interpretation positive of one party, namely, the primary definers and/or negative of the opposing other, namely, the secondary definers, as defined by Hall, Critcher, Jefferson, Clarke, and Robert (1978). It occurs even when the given news outlet attempts to downplay its own voice and appear objective by distancing itself from the speech content and quoting voices representing both sides of the conflict.

The New York Times, in its coverage of the January 25 protests, voiced the anti-regime protesters as the primary definers of the situation similar to Youssef's (2012) findings with regard to a different American news outlet, namely, The Washington Post. The New York Times adopted their definition of the antiregime protests, their detailed description of the violence exercised against them by the state police and the regime's supporters, as well as their depiction of the autocratic regime. In contrast, the authority figures' negative portrayal of the protests, their intention to peacefully resolve the nation's conflict, and their ability to put an end to the protests were challenged by the American newspaper in the immediate context surrounding their cited utterances.

In opposition to the international newspaper's quoting of sources in its coverage of the anti-Mubarak protests, it utilized the 
quoted sources on the part of Morsi's regime and its allies as the main definers of the situation as opposed to their opponents voiced as the secondary definers and much less quoted. To expound, the latter's generic statements were modified by the newspaper to appear contrasted with the former's in a way that made the latter's view seem, illogical, illegitimate, and unjustified. The international newspaper, on the contrary, sought the regime's favorable depiction of Morsi's decrees as a means to democracy. It reported the president's and his proponents' contextual details of Egypt's internal political crisis and divide in association with schemes by institutions left intact from Mubarak-era government without attempting to question their utterances.

In contrast, in the reporting of the conflicting sides in the AlMasry Al-Youm's pre-Feb. 4 Friday of Departure coverage, it utilized the regime's officials and its supporters as the primary definers, as similarly spotlighted in Youssef (2012). However, the regime's supporters were much more quoted to show their representativeness. The national news outlet adopted their definition of the anti-regime protests as a threat to the nation's stability, of the few remaining forces in Tahrir Square after Mubarak's promised reforms on Feb. 1 as connivers against both the nation's interests and the gains of the youth revolution, and of Mubarak as the defender of the nation.The protesters, on the contrary, were the counter definers since their utterances were either marginalized by revolving only around brief anti-regime chants and by being quoted to be only discredited or totally silenced. In the national newspaper's post-Friday of Departurestage of voicing the conflicting sides, it much frequently quoted and adopted the anti-regime protesters' detailed version of the story of their protests and negative depiction of the autocratic collapsing regime, while the regime's voice was almost totally disregarded. That is, the latter became the counter definers.

Contrary to the Egyptian newspaper's sourcing of voices in its coverage of the January 25 protests, it highly quoted the antiMorsi protesters as the main definers of the anti-regime protests as 
representing the public will and the revolutionary legitimacy. This highlights Eissa's (2015) emphasis on the independent news outlet's frequent quoting and personalizing of the National Salvation Front leaders. Moreover, the newspaper spotlighted their definition of the nation's internal political crisis as caused by Morsi's decrees and the MB's domination of Egypt's political life along with their initiated violence against the former. It also adopted the protesters' definition of the military's intervention as necessary to overcome the crisis and meet the public's demands. In contrast, the regime's and the MB's very much less quoted voices defending the presidential legitimacy against what they called the military coup and the former regime remnants' conspiracy were marginalized by presenting their utterances against those of the opposition. Hence, their utterances were challenged and undermined and seemed irrational. That is, they represented the counter definers who were also fully silenced in some of the examined reports in the national newspaper similar to their hardly quoted public Islamist supporters, which lends support toEissa's (2015) study where the MB's sources were dehumanized and disregarded in the national independent news website

It is important to note that Bell (1991), Chen $(2005,2007)$, Eissa (2015), Fairclough (2003), and Richardson (2007) believed that reporting verbs can contribute to deepening polarization, hence detecting a news outlet's perspective towards the quoted voices since they function as an evaluative tool through which the reporter(s) integrate their judgment with the given voices. However, I see that these verbs cannot function as such in isolation from the rest of the representing and represented discourses elements. That is, the neutrality, positivity, and negativity of the employed reporting verbs are enormously influenced by the content of a given speaker's utterance, the context in which such utterance is inserted, the way it is positioned, the quotation type used, and/or the circumstantial element(s) if available in the reporting clause. All these elements can either make the reported speaker appear in a positive or 
negative position and his statement more or less significant or downplay and devalue the positivity or negativity of his words. In the present study, it was found that the neutral reporting verbs were the most used in the examined newspapers' coverage of both Egyptian protests followed by the positive processes, and finally the negative processes used very restrictedly (see Tables 1-4, pp. 30-37). Nevertheless, the newspapers' representation of the conflicting parties was not impartial. Moreover, the positive ingroup image in each newspaper at hand was more prominent than the negative outgroup image though both groups were much more frequently reported using neutral and positive verbal processes than negative verbal processes. Accordingly, I believe, in disagreement with Chen $(2005,2007)$, that positive and negative reporting verbs do not necessarily indicate a relationship of conflict between the speaker and the involved social actor(s) and that the neutral reporting verbs do not by necessity imply unbiased attitude towards the quoted speaker and utterance unless they are interpreted in association with the aforesaid elements (see Section 5.1).

The present study, moreover, unveiled the power relations that shaped the January 25 and June 30 protests discourse in the examined newspapers. The study revealed that each newspaper's ideological stance towards both Egyptian protests was tremendously fed by its political affiliation, hence giving support to the notion of the media as an ISA in the sense of Althusser (1971). Consequently, it can be drawn from the present study that media discourse whether national or international is utilized at times of conflict to maintain or counter unequal relations of power in a society. The study displayed such unequal power relations might be resisted based on a given media outlet's evaluation of the power balance during times of conflict. This was clearly embodied in the examined national newspaper's overt bias against Morsi's, which highlighted its resistance to the official mainstream ideological perspective during his rule. The national newspaper, in fact, represented the liberal media which 
endorsed the opposition and the Egyptian public then as opposed to Morsi's Islamist supportive media which played the same role adopted by the state-owned media during Mubarak's era (see Sections 4 \& 5.3). However, perhaps other elite powerful institutions and political groups that Morsi did not have a power grab over were covertly dictating such media outlets in an attempt to protect their own economic and political interests, such as the remnants of Mubarak's regime, as claimed then by Morsi's allies (Sharp, 2013). This demonstrates the examined international newspaper's more consistent reflection of the official mainstream ideological views during both investigated protests than that of the national newspaper at hand during particularly the anti-Morsi protests.

It is my hope that this study will open horizons for further CDA research on press discourse, especially news coverage of mass protests and revolutions in Egypt, regionally, and beyond. This study captured the similarities and differences that existed across national and international news outlets in their coverage of both Egyptian protests. Thus, its results could be an indication on how such news outlets covered both protests. However, only two out of many daily newspapers were selected for analysis, hence eliminating a possible range of alternative or matching voices in the media. Accordingly, examining a wider sample of newspapers is highly recommended in further studies including state-owned and partisan newspapers whether nationally or internationally, other Middle East newspapers, and other European newspapers written in different languages. 


\section{References}

Adams, I. (2001). Political ideology today. Manchester: Manchester University Press.

Alexander, H. (2013, July 4). World reaction to Egypt coup.The Telegraph. Retrieved from http://www.telegraph.co.uk/news/worldnews/africaandindianocean/ egypt/10159658/World-reaction-to-Egypt-coup.html

Alhumaidi, M. (2013).A critical discourse analysis of Al-Ahram and AlJazeera's online coverage of Egypt's 2011 revolution (Doctoral dissertation).University of Florida, Gainesville, USA. Retrieved from http://ufdc.ufl.edu/UFE0046068/00001

Althusser, L. (1971). Ideology and ideological state apparatuses: Notes towards an investigation. In L. Althusser (Ed.), Lenin and philosophy, and other essays (pp. 121-173). (B. Brewster, Trans). New York: Monthly Review Press.

Ansolabehere, S., Lessem, R., \& Snyder, J. (2004).The political orientation of newspaper endorsements in U.S. elections, 1940-2002. Retrieved from https://www.andrew.cmu.edu/user/rlessem/endorse.pdf

Arab West Report. (2008). From decorative democracy to journalistic potency: Egyptian print media today and tomorrow. Retrieved from http://arabwestreport.info/year-2008/week-19/2-decorative-democracyjournalistic-potency-egyptian-print-mediatoday-and-tomorrow

Ashley, L. \& Olson, B. (1998). Constructing reality: Print media's framing of the women's movement, 1966-1986. Journalism and Mass Communication, 75(2), 263-277.

Bell, A. (1991). The language of news media. Oxford: Blackwell.

Blommaert, J. (2005). Discourse: A critical introduction. Cambridge, UK: Cambridge University Press.

Blommaert, J. \&Bulcaen, C. (2000).Critical discourse analysis.Annual Review of Anthropology, 29, 447-466.

Brennan, A. (2012, October 27). The New York Times endorses Obama again.

Retrieved

from

http://politicalticker.blogs.cnn.com/2012/10/27/the-new-york-timesendorses-obama-again/

Chen, L. (2005). Transitivity in media texts: Negative verbal process sub-functions and narrator bias. IRAL, 43, 33-51.

Chen, L. (2007). Analyzing attitude: Positive verbal process sub-functions and media bias.RASK International Journal of Language and Communication, 25, 2555 . 
Chomsky, N. (1997, October). What makes mainstream media mainstream.Z Magazine.Retrieved from: http://www.chomsky.info/articles/199710-.htm

Chouliaraki, L. \&Fairclough, N. (1999).Discourse in late modernity: Rethinking critical discourse analysis. Edinburgh: Edinburgh University Press.

Cooper, K. (2008). Politics and priorities: Inside the Egyptian press. Arab Media and Society. Retrieved from

http://www.arabmediasociety.com/articles/downloads/20080929131720_A MS6_Ken_Cooper.pdf.

Cotter, C. (2010).News talk: Investigating the language of journalism. New York, USA: Cambridge University Press.

Cottle, S. (2000).Rethinking news access.Journalism Studies, I(3), 427-448.

deGraaf, j. j. (2008). Al-Jazeera English: the opinion and the other opinion: A comparison between ideologies in CNN International and Al-Jazeera English (MA thesis). University of Utrecht, Netherlands. Retrieved from

https://www.researchgate.net/publication/27708757_Al-

Jazeera_English the_Opinion_and the_Other_Opinion_A_comparison_betw een_ideologies_in_CNN_International_and_Al-Jazeera_English

Dunlevy, M. (1998).Objectivity. In M. Breen (Ed.), Journalism: Theory and practice (pp. 119-138). Paddington, NSW: Macleay Press.

Eissa, M. M. (2015). Polarized discourse in the Egyptian news: Critical discourse analysis perspective. Dinamikallmu, 15 (1), 35-65.

El Issawi, F. (2014).Egyptian media under transition: In the name of the regime....In the name of the people? London: London School of Economics, POLISMedia and Communications.

Elmasry, M. H. (2012). Producing news in Mubarak's Egypt: An analysis of Egyptian newspaper production during the late Hosni Mubarak era.Journal of Arab \& Muslim Media Research, 4(2 \& 3), 121-144.

Elmasry, M. H., \& El-Nawawy, M. (2014). One country, two eras: How three Egyptian newspapers framed two presidents. Global Media Journal: Mediterranean Edition, 9(1), 27-39.

El-Nashar, M. M. M. (2014). Media bias: A critical discourse analysis of the representation of the Egyptian army in The New York Times. International Journal of Arts \& Sciences, 7(4), 265-292.

Fairclough, N. (1989).Language and power. London: Longman.

Fairclough, N. (1992). Discourse and social change. Cambridge: Polity Press.

Fairclough, N. (1993). Critical Discourse Analysis and the Marketization of Public Discourse: The Universities. Discourse \& Society, 4(2), 133168.

Fairclough, N. (1994). Discourse and social change. Massachusetts: Polity Press. 
Fairclough, N. (1995a). Critical discourse analysis: The critical study of language. London: Longman.

Fairclough, N. (1995b). Media discourse. London: Edward Arnold.

Fairclough, N. (2003). Analyzing discourse: Textual analysis for social research. London: Routledge.

Fairclough, N. (2006). Language and globalization. New York: Routledge.

Fairclough, N. \&Wodak, R. (1997).Critical discourse analysis.In T. A. van Dijk (Ed.), Discourse as social interaction. Discourse studies: A multidisciplinary introduction (pp. 258-284). London: Sage Publications.

Fowler, R. (1991).Language in the news: Discourse and ideology in the press. London: Routledge.

Gitlin, T. (1980).The whole world is watching: Mass media in the making and unmaking of the new left. Berkeley, CA: University of California Press.

Green, D. (2011, February 17). What caused the revolution in Egypt? The Guardian. Retrieved from

http://www.theguardian.com/global-

development/povertymatters/2011/feb/17/what-caused-egyptianrevolution

Hall, S., Critcher, C., Jefferson, T., Clarke, J., \& Roberts, B. (1978).Policing the crisis: mugging, the state, and law and order. London: Macmillan.

Harper, C. J. (2014). 25 TV: A case sutdy of the media during the Egypitanuprising American Internatinal Journal of Social Science, 3 (4), 35-46.

Hauslohner, A. (2013, July 2). Egypt's Morsi defiant under pressure as deadline looms. The Washington Post. Retrieved from

$\mathrm{http}: / / \mathrm{www} . w a s h i n g t o n p o s t . c o m / w o r l d / m i d d l e+e a s t / 2013 / 07 / 02 / \mathrm{fcb} 11 \mathrm{aa} 0$ e315-11e2-a11e-c2ea876a8f30 story.html

Herman, E. S. \& Chomsky, N. (2002).Manufacturing consent: The political economy of the mass media. London: Pantheon.

Hertog, J.K. \& McLeod, D.M. (1995). Anarchists wreak havoc in downtown Minneapolis: A multi-level study of media coverage of radical protest. Journalism \& Mass Communication Monographs, 151, 1-48.

Hodge, R. \& Kress, G. (1993).Language as ideology. London: Routledge.

Holmes, A. A. (2012). There are weeks when decades happen: Structure and strategy in the Egyptian revolution. Mobilization: An International Journal, 17(4), 391-410.

Huckin, T. (2002). Critical discourse analysis and the discourse of condescension. In E. Barton \& G. Stygall (Eds.), Discourse studies in composition. Hampton: University of Utah. Retrieved from 
http://www.writing.ucsb.edu/wrconf08/Pdf_Articles/Huckin_Article.pdf Ibrahim, R. (2013, June 25). Obama to Egyptian Christians: Don't protest the Brotherhood. FrontPage MAG. Retrieved from www.frontpagemag.com/2013/raymound-ibrahim/u-s-asks-egyptschristians-not-to-oppose-morsi/

Iggers, J. (1999).Good news, bad news: Journalism ethics and the public interest. Boulder: Westview Press.

Juan, L. (2009). Intertextuality and national identity: Discourse of national conflicts in daily newspapers in the United States and China. Discourse \& Society, 20 (1), 85-121.

Lagonikos, I. T. (2005).Ideology in editorials: A comparison of selected editorials in English-medium newspapers after September 11 (MA thesis). Rhodes University, South Africa. Retrieved from

$\mathrm{http}: / / \mathrm{www} . i b r a r i a n . n e t / n a v o n / . . /$ Ideology_in_Editorials_A_Comparison_ of_Selected_.pdf?

Lawrence, R. (2000). The politics of force: Media and the construction of police brutality.Berkeley: University of California Press.

Manning, P. (2001). News sources: A critical introduction. London: Routledge.

Martin, D. (2013, July 5). We'll work with regime, says Hague: Foreign Secretary says Britain does not support Egypt's military intervention and coup was 'dangerous thing'. The Daily Mail. Retrieved from http://www.dailymail.co.uk/news/article-2356534/William-Haguesays-Britain-does-support-Egypts-military-intervention-coupdangerous-thing.html

McLeod, D. M. (1995).Communicating deviance: The effects of television news coverage of social protest.Journal of Broadcasting and Electronic Media, 39(1), 4-19.

McLeod, D. M. \&Hertog, J. K. (1992). The manufacture of public opinion for reporters: Informal cues for public perceptions of protest groups. Discourse \& Society, 3 (3), 259-275.

McQuail, D. (1993). Media performance: Mass communication and the public interest. London: Sage.

Molotch, H. \& Lester, M. (1974). News as purposive behavior: On the strategic use of routine events, accidents, and scandals. American Sociological Review, 39, 101-112.

Murdock, G. (2000). Reconstructing the ruined tower: Contemporary communications and questions of class.In J. Curran \& M. Gurevitch (Eds.), Mass media and society (pp. 7-26). London: Arnold.

Okrent, D. (2004, July 25). The public editor; Is The New York Times a liberal newspaper? The New York Times.Retrieved from 
http://www.nytimes.com/2004/07/25/opinion/the-public-editor-is-the-newyork-times-a-liberal-newspaper.html

Pasha, T. (2011).Islamists in the headlines: Critical discourse analysis of the representation of the Muslim Brotherhood in Egyptian newspapers. (Doctoral dissertation). U.S.A.: University of Utah.

Richardson, J. E. (2006). Who gets to speak? A study of sources in the broadsheet press.In E. Poole \& J. E. Richardson (Eds.), Muslims and the news media (pp. 103-115). London: I.B. Tauris.

Richardson, J. E. (2007). Analyzing newspapers: An approach from critical discourse analysis. New York: Palgrave Macmillan.

Rogers, R. (2004). An introduction to critical discourse analysis in education. London: L. Erlbaum Associates.

Ross, T., Moore, M., \&Swinford, S. (2011, January 28). Egypt protests: America's secret backing for rebel leaders behind uprising. The Telegraph. Retrieved from http://www.telegraph.co.uk/news/worldnews/africaandindianocean/ egypt/8289686/Egypt-protests-Americas-secret-backing-for-rebelleaders-behind-uprising.html

Rubin, B. (2015). The Middle East: A guide to politics, economics, society and culture. New York: Routledge.

Rugh, W. A. (2004). The Arab mass media: Newspapers, radio and television in Arab politics. Westport, Conn.: Greenwood Press.

Sharp, J. M. (2013). Egypt: Background and U.S. relations. Congressional Research Service, 1-18. Retrieved from

https://digital.library.unt.edu/ark:/67531/metadc306543/m1/1/high_res_d/RL33003_2 014Jun05.pdf

Sornig, K. (1989). Some remarks on linguistic strategies of persuasion. In R. Wodak (Ed.), Language, power and ideology: Studies in political discourse (pp. 95-113). Amsterdam and Philadelphia: John Benjamins.

Stenvall, M. (2008).Unnamed sources as rhetorical constructs in news agency reports.Journalism Studies, 9 (2), 229-243.

Teo, P. (2000) Racism in the news: A critical discourse analysis of news reporting in two Australian newspapers. Discourse Society, 11(1), 7-49.

Tuchman, G. (1978). Making news: A study in the construction of reality. London: Free Press; Collier Macmillan.

vanDijk, T. A. (1980). Macrostructures: An interdisciplinary study of global structures in discourse, interaction and cognition. Hillsdale, New Jersey: Lawrence Erlbaum Associates Publishers. 
vanDijk, T. A. (1983). Discourse analysis: Its development and application to the structure of news. Journal of Communication, 33, 20-43.

vanDijk, T. A. (1988). News as discourse. New Jersey \& London: Lawrence Erlbaum Associates Publishers.

vanDijk, T. A. (1991). Racism and the press. London: Routledge.

vanDijk, T. A. (1993a). Elite discourse and racism. London: Sage Publications.

vanDijk, T. A. (1993b). Principles of critical discourse analysis.Discourse and Society, 4(2), 249-283.

vanDijk, T. A. (1995a).Aims of critical discourse analysis. Japanese Discourse, 1, $17-27$.

vanDijk, T. A. (1995b). Discourse analysis as ideology analysis. In C. Schaffner\& A. Wendem (Eds.), Language and peace (pp. 17-33). Dartmouth: Dartmouth Publishing Company Limited.

vanDijk, T. A. (1996). Discourse, opinions and ideologies.In C. Schaffner\& H. Kelly-Holmes (Eds.), Discourse and ideologies (pp. 737).Clevedon: Multilingual Matters Ltd.

vanDijk, T. A. (1997). Discourse as interaction in society. In van Dijk, T. A. (Ed.).Discourse as social interaction. Discourse studies: A multidisciplinary introduction (pp. 1-40). London: Sage Publications.

vanDijk, T. A. (1998). Opinions and ideologies in the press. In A. Bell \& P. Garrett (Eds.), Approaches to media discourse (pp. 21-36). Oxford: Blackwell.

vanDijk, T. A. (2000). Ideology: A multidisciplinary approach. London: Sage Publications.

vanDijk, T. A. (2001). Critical discourse analysis.In D. Tannen, D. Schiffrin\& H. Hamilton (Eds.), Handbook of discourse analysis (pp. 352-371). Oxford: Blackwell.

vanGinneken, J. (2002). Global news: A critical introduction. London: Sage.

Wayne. M. (2003).Marxism and media studies: Key concerns and contemporary trends. London: Pluto Press.

Wodak, R. (1996). Disorders of discourse. London: Longman.

Youssef, A. (2012). A critical analysis on media coverage of the Egyptian revolution: The case of Al-Ahram, Al-Masry Al-Youm, The Telegraph and The Washington Post (MA thesis). Örebro University, Sweden. Retrieved from http://www.divaportal.org/smash/get/diva2:540808/FULLTEXT01.pdf

Zaher, A. (2009). A critical discourse analysis of news reports on the Israeli/Palestinian conflict in selected Arab and Western newspapers (Doctoral dissertation). Nottingham Trent University, UK.Retrieved from irep.ntu.ac.uk./id/eprint/146/ 


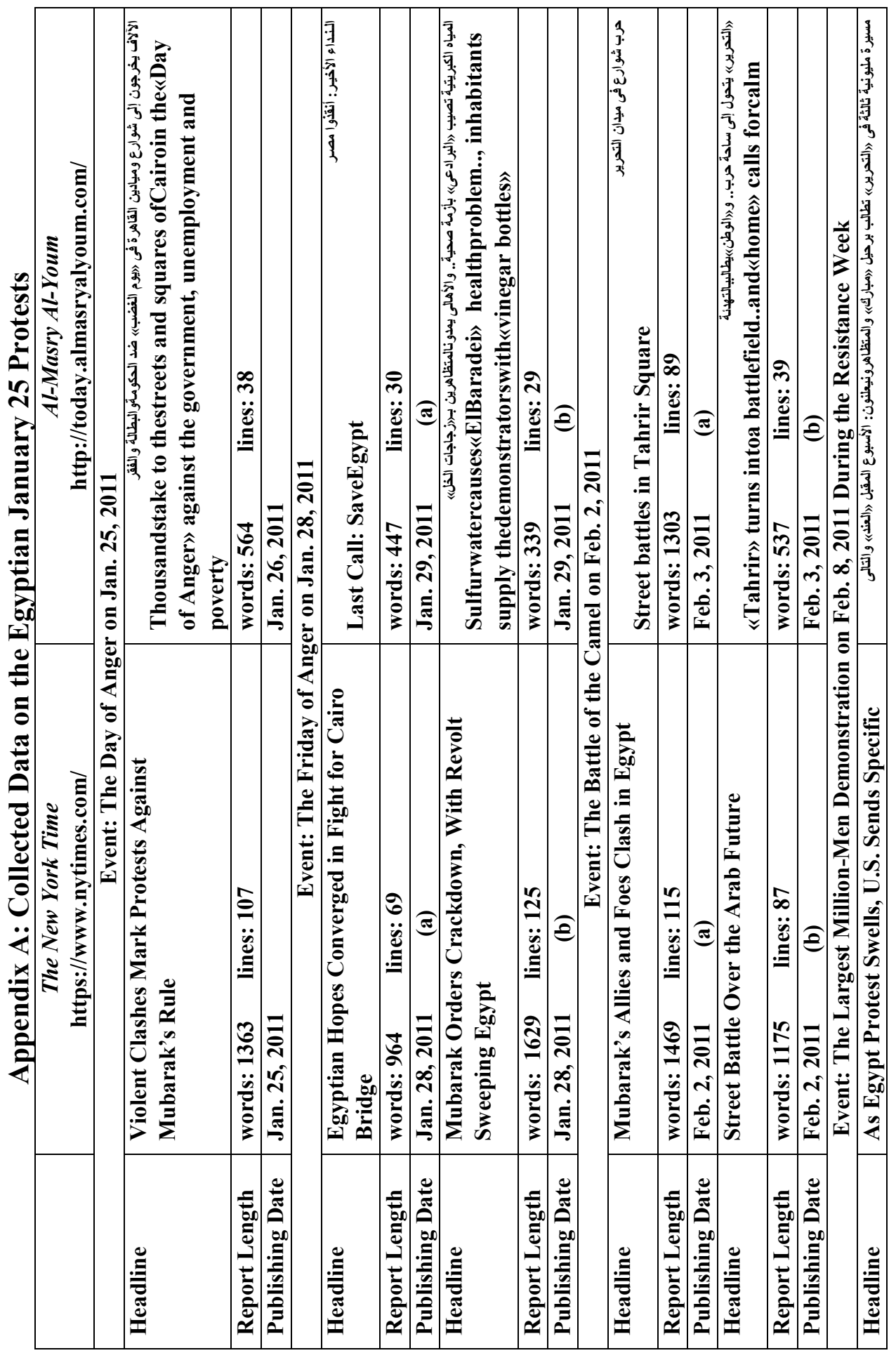




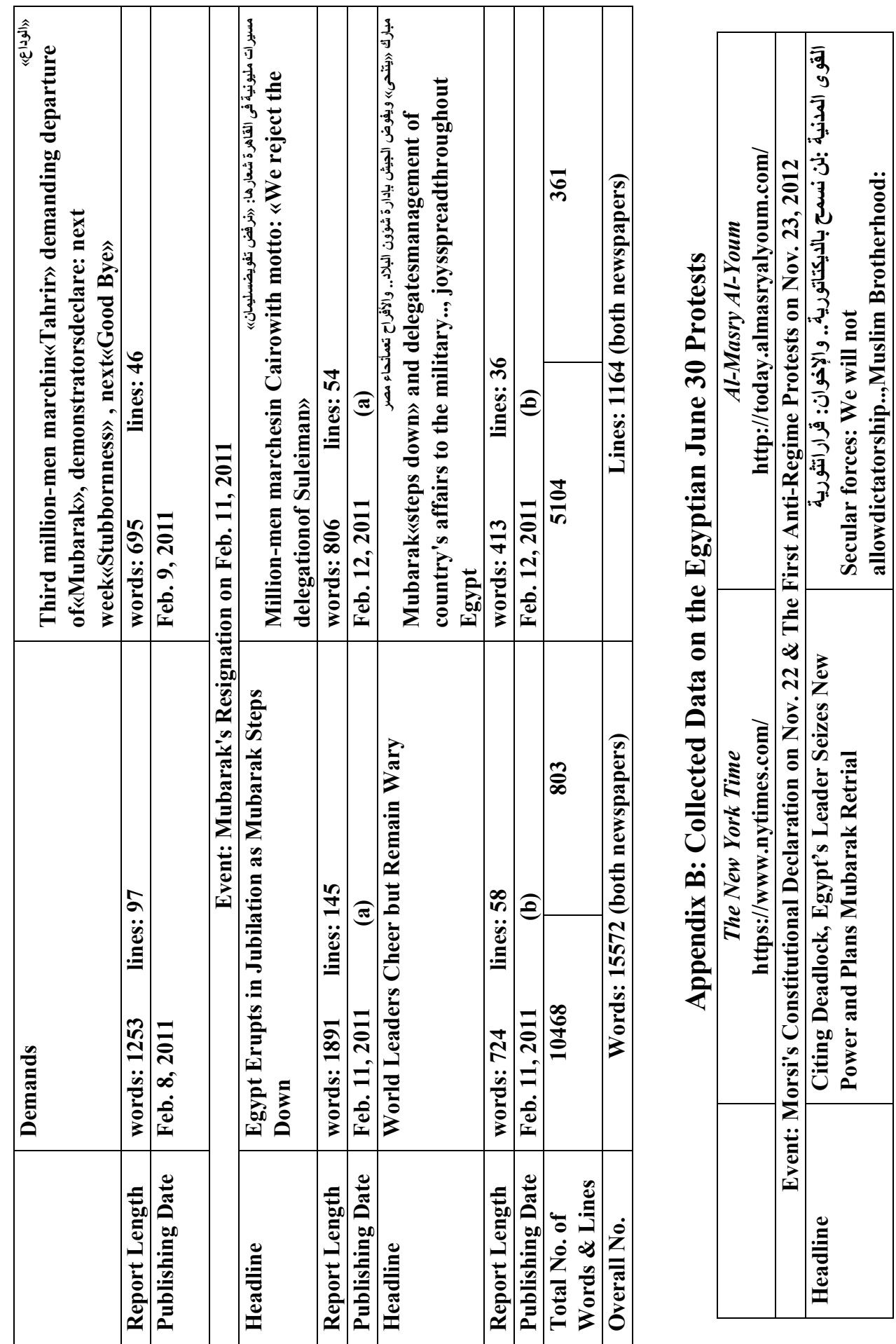

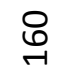




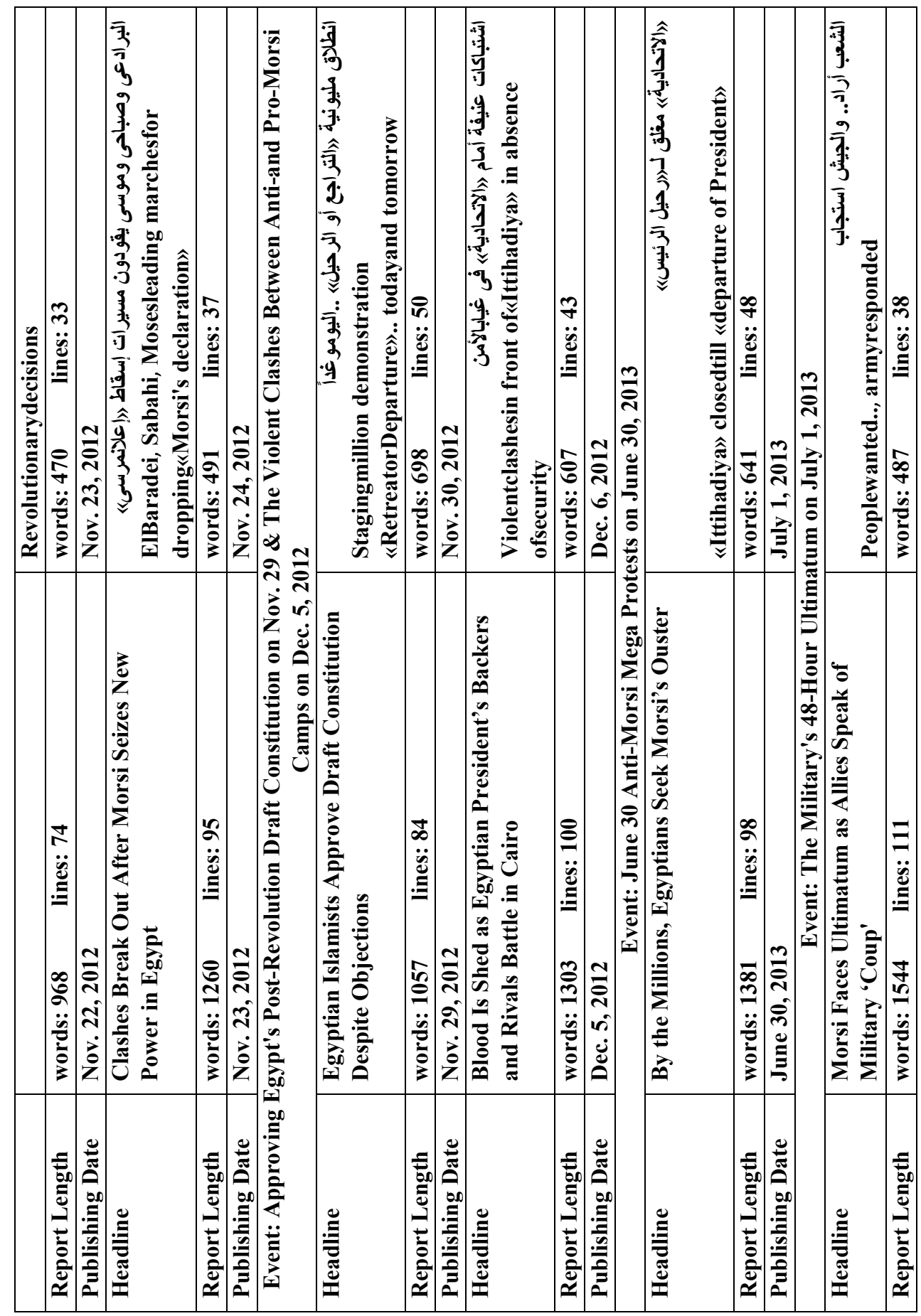




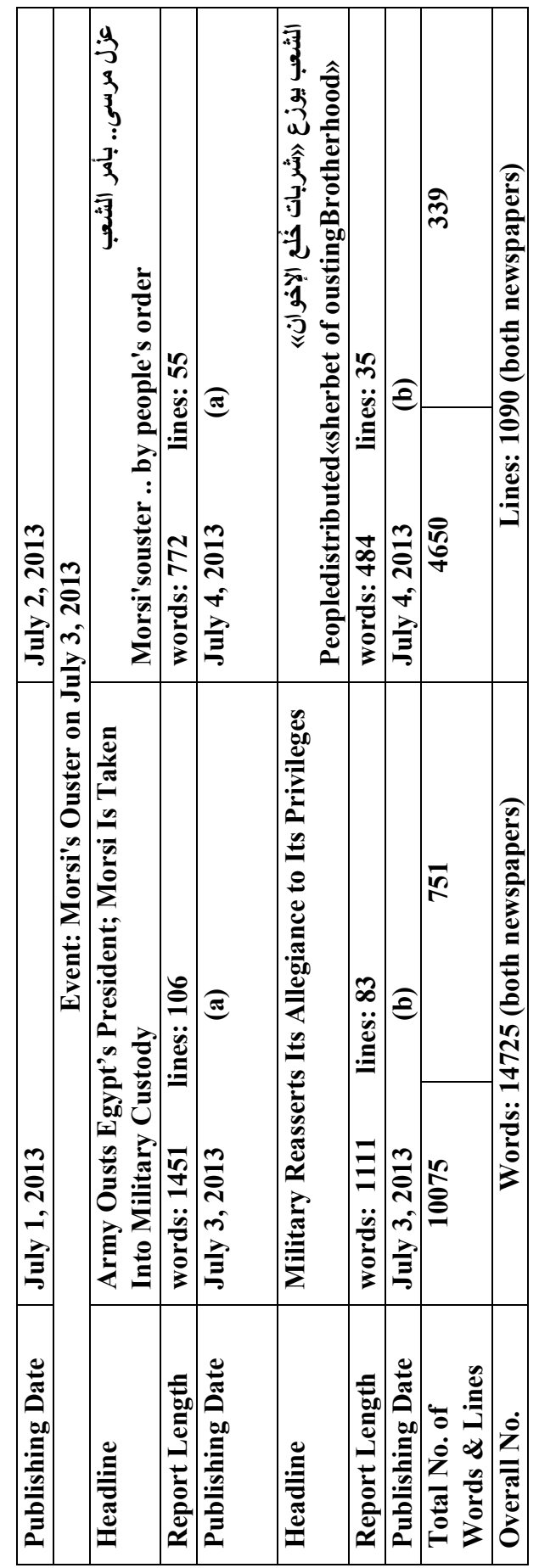

